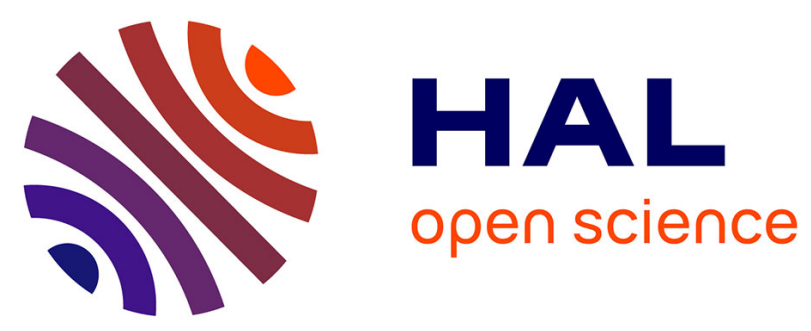

\title{
Recent changes in precipitation, ITCZ convection and northern tropical circulation over North Africa (1979-2007)
}

Bernard Fontaine, Pascal Roucou, Marco Gaetani, Romain Marteau

\section{- To cite this version:}

Bernard Fontaine, Pascal Roucou, Marco Gaetani, Romain Marteau. Recent changes in precipitation, ITCZ convection and northern tropical circulation over North Africa (1979-2007). International Journal of Climatology, 2011, 31, pp.633-648, DOI: 10.1002/joc.2108. 10.1002/joc.2108 . hal-00414681

\section{HAL Id: hal-00414681 \\ https://hal.science/hal-00414681}

Submitted on 12 Jan 2011

HAL is a multi-disciplinary open access archive for the deposit and dissemination of scientific research documents, whether they are published or not. The documents may come from teaching and research institutions in France or abroad, or from public or private research centers.
L'archive ouverte pluridisciplinaire HAL, est destinée au dépôt et à la diffusion de documents scientifiques de niveau recherche, publiés ou non, émanant des établissements d'enseignement et de recherche français ou étrangers, des laboratoires publics ou privés. 
Recent changes in precipitation, ITCZ convection and northern tropical circulation over North

Africa (1979-2007)

Bernard Fontaine ${ }^{1}$, Pascal Roucou ${ }^{1}$, Marco Gaetani $^{2}$ and Romain Marteau ${ }^{1}$

(1) Centre de Recherches de Climatologie (UMR 5210 CNRS / Université de Bourgogne), F21000 DIJON, France

(2) Istituto di Biometeorologia del CNR, Roma, Italy.

fontaine@u-bourgogne.fr

\begin{abstract}
This article focuses on some recent changes observed in the tropics with special emphasis on the African monsoon region using high resolution gridded precipitation from the Climatic Research Unit (period 1979-2002), outgoing long-wave radiation at the top of the atmosphere from the National Oceanic and Atmospheric Administration and atmospheric reanalyses from the Climate Prediction Center (NCEP-DOE2, period 1979-2007). The results show a rainfall increase in North Africa since the mid-90s with significant northward migrations of rainfall amounts i.e., $+1.5^{\circ}$ for the $400 \mathrm{~mm}$ July-September isohyets, while deep convection has significantly increased and shifted northward. The subsidence branch of the northern meridional overturning has also been reinforced and shifted by $1^{\circ}$ lat northward in winter. At larger scale an unambiguous reorganization of the circulation with increasing subsidence in high troposphere over the Mediterranean and increasing ascendance in the African Intertropical Convergence Zone in northern summer has been noticed in the meridional cell overturning. After years 1993-94, the migration of the Saharan heat low towards North West has been more marked $\left(+1^{\circ}\right.$ to $+2^{\circ}$ in latitude; -1 to $-2^{\circ}$ in longitude) while its centre intensified at the peak of the tropical rainy season $(+10$ gpm thickness in the 700-925 hPa layer). These changes are associated with significant reinforcements of the southwesterly low-level winds and Tropical Easterly jet, and with a northward shift of the African Easterly jet. Analyses of Global Circulation Model outputs issued from Intergovernmental Panel on Climate Change (A1b scenario and from forced experiments on the ARPEGE-climat (Action de Recherche Petite Echelle Grande Echelle) Atmospheric Global Circulation Model show that at least part of these changes could be due to the recent warming observed in the Mediterranean/Saharan region.
\end{abstract}




\section{Introduction}

Historical analysis of rainfall records and atmospheric data is for a long time an important field of research, in particular over North Africa where, after the abnormally wet rainy seasons during the 50s, a severe drought occurred from the late 60s until the middle of 90s. However, based on recent observations, there is now a consensus based on the empirical evidence of a partial recovery of the rainfall amount in these regions over the last 25 years (Dai et al., 2004; Nicholson, 2005, among others). Dai et al. (2004) mentioned that Sahel rainfall in the 1990s has recovered considerably from the severe dry years in the early 1980s, while Nicholson (2005) noticed that southward to $16^{\circ} \mathrm{N}$ the positive trend is most marked in the western and central Sahel than eastward. More recently Solomon et al. (2007) report the rainfall tendency observed between 1979 and 2005 over West Africa whereas Lebel and Ali (2008) show that in Western Sahel the 1990-2007 mean equals to the1970-1989 mean, both being lower than the 1950-1969 mean.

Other studies have focused on related topics but on larger scales. For example, Lau and $W u$ (2007) reveal two opposite time evolutions in the occurrence of rainfall events in the tropics, in overall agreement with the Climate Research Unit's (CRU) gauge-only rainfall data over land: a negative trend in moderate rain events and a positive trend in heavy and light rain events. Positive trends in intense rain located in deep convective cores of the InterTropical Convergence Zone (ITCZ), South Pacific Convergence Zone, Indian Ocean and monsoon regions have been also noticed by Lau and Wu (2007) while Chen et al. (2002) and Zhao and Moore (2008), among others, pointed out possible changes in the overturning circulation.

The purpose of this study is to quantify and discuss a few convergent signals relative to the West African monsoon domain, such as those observed in rainfall fields, deep convection, overturning circulation and atmospheric circulation. For this we focus on the recent period which benefits from Satellite observations and does not include the sudden Pacific warming of 1976 - 1977. We also select different file types for a single independent variable in order to give more robustness to the results, using mainly: (i) monthly precipitation from the CRU TS 2.1 data-set which comprises 1224 grids of observed climate, for the period 1901-2002, and covers the global land surface at 0.5 degree resolution (see New et al, 2002 and Mitchell et al, 2004); (ii) daily in situ rainfall (30 stations, period 1990-2008) used in the international African Monsoon Multidisciplinary Analyses (AMMA) and CATCH experiment (CATCH=Couplage de l'Atmosphère Tropicale et du Cycle Hydrologique) over the AMMA- 
CATCH Niger mesoscale site $\left(1.6^{\circ} \mathrm{E}-3.2^{\circ} \mathrm{E} ; 13^{\circ} \mathrm{N}-14^{\circ} \mathrm{N}\right.$ (see for more details Le Barbé et al., 1997 ; Lebel et al., 1997 and D'Amato et al., 1998); (iii) the daily NOAA Interpolated OLR data (see Liebmann and Smith, in the Bulletin of the American Meteorological Society, June 1996 for details) with gaps filled with temporal/spatial interpolation and provided on a regular $2.5^{\circ} \times 2.5^{\circ}$ grid over the period 1979-2007; (iv) the Climate Prediction Center NCEP/DOE2 atmospheric reanalyses provided on a regular $2.5^{\circ} \times 2.5^{\circ}$ grid over the period 1979-2007; (v) selected outputs from Intergovernmental Panel on Climate Change (IPCC) models and sensitivity experiments performed on the ARPEGE-climat general circulation model by the AMMA community (ARPEGE = Action de Recherche Petite Echelle Grande Echelle).

Section 2 presents a few basic rainfall and outgoing Longwave Radiation (OLR) signals diagnosed recently in North Africa, whereas section 3 presents associated trends detected in the location and intensity of selected descriptors of the West African Monsoon system. Section 4 discusses the plausible hypotheses able to explain the results using model outputs.

\section{Recent changes in precipitation and OLR over North Africa}

The first question obviously is whether some robust changes are observable in terms of rainfall and deep convection over the recent period. Figure 1a displays the evolution of monthly rainfall during northern summer observed with the CRU data between $15^{\circ} \mathrm{W}$ and $30^{\circ} \mathrm{E}$ in North Africa as a function of latitudes, while figure $1 \mathrm{~b}$ shows the significant increase in precipitation (yellow shadings) from April to October between the sub-periods 1979-1992 and 1994-2002. Two points must be mentioned: (i) south of $10^{\circ} \mathrm{N}$ of latitude, the main augmentations are concentrated in April and June during the first Guinean rainy season then in October during the second Guinean rainy season; (ii) north of $10^{\circ} \mathrm{N}$ of latitude, in Sahelian regions, augmentations concern the months of August and October at times of peak and end of the tropical rainy season. Panels at bottom (1c-e) give more details for the Western, Central and Eastern African sub-windows : they show that the most significant changes are observed from August to October in Sudan-Sahel between $0^{\circ}$ and $15^{\circ} \mathrm{E}$ (panel 1d). Notice however that such a temporal evolution of long-term rainfall amounts cannot be interpreted in terms of linear trends and is sensitive to the period and domain selected. For years 1950-2007 only a slight recovery over the recent period in the Central Sahel has been noticed by Lebel and Ali (2008) with larger rainfall in July by comparison to the dry 1970-1989 period whereas the rainfall regime of August and September remained unchanged. Figure 2 indicates that the last statement is also observed on the most recent period (1990-2008) through daily rainfall 
recorded over the AMMA-CATCH Niger mesoscale site $\left(1.6^{\circ} \mathrm{E}-3.2^{\circ} \mathrm{E} ; 13^{\circ} \mathrm{N}-14^{\circ} \mathrm{N}\right)$, a small but representative domain of the Sahel belt. However most of interannual rainfall evolutions do not present any significant linear trend (at $\mathrm{p}=0.1$, significant level $=90 \%$ ) except for July (Fig $2 b$ ) where one can notice a positive linear trend at $\mathrm{p}=0.01$ (significant level $=99 \%$ ).

\subsection{Are these variations interpretable in terms of latitudinal variations of}

\section{isohyets?}

To answer this question time evolutions of the rainfall amounts and of the latitudinal locations of a few specific isohyets averaged between $5^{\circ} \mathrm{N}$ and $20^{\circ} \mathrm{N}$ are presented in figures 3 and 4 respectively, for different longitudinal windows. Panel 3 a illustrates the interannual and low frequency (> $8 \mathrm{yr}$ ) variability of annual (top), July-September (middle) and August (bottom) rainfall amounts averaged over African longitudes $\left(20^{\circ} \mathrm{W}-30^{\circ} \mathrm{E}\right)$; panel $3 \mathrm{~b}$ contrasts the annual and July-September rainfall evolutions over the Western, Central and Eastern African windows. Curves are bolded where changes in time are significant at $p=0.1(90 \%)$. A significant augmentation in annual amounts is clearly attested in the 80s and 90s, i.e., from less than $800 \mathrm{~mm}$ in 1983 to 1170 in 1999 (Fig. 3a). Notice that the signal seems to be stronger in July-September over the central parts of North-Africa (from $720 \mathrm{~mm}$ in 1983 to 1080 in 1996, Fig. 3b). This is concomitant of a northward displacement of isohyets as illustrated in figure 4: the annual $(1000 \mathrm{~mm})$ and July-September $(350 \mathrm{~mm})$ isohyets have been significantly shifted by about $+1^{\circ}$ latitude in mean for the whole Africa (Fig 4a), and by $+1.5^{\circ}$ for the central and eastern windows (red and green curves in Fig. $4 \mathrm{~b}$ ). Once again these changes are not interpretable in terms of linear trends over the whole period.

\subsection{Interannual variability in deep convection}

OLR data measure the direct emission from oceanic and land surfaces but also from clouds and dust in the atmosphere. They allow thus clear distinction between clear-sky regions, which concentrate the highest OLR, and deep convective regions where the highest and coldest clouds dominate. Bimonthly OLR differences computed between the 14 last and the 14 first years of the 28-year period 1979-2007 are presented in figure 5. Notice that signals of trend in the Tropics and subtropics are seen more significant over the African monsoon longitudes, i.e., mainly between $30^{\circ} \mathrm{W}$ and $50^{\circ} \mathrm{E}$. Indeed these regions concentrate 2 opposite signals: positive changes (i.e., increasing OLR) around the Mediterranean region and the Arabia peninsula in northern spring (red shadings in Fig.5 b,c), and negative changes (i.e., decreasing OLR) in lower latitudes such as West Africa in summer and the Indian 
subcontinent in Autumn (blue shadings in Fig. 5d,e). According to the Stefan's law, positive values indicate an increase with time of the warming at the Earth surface in dry subtropics where subsidence occurs (no high clouds). By contrast negative values suggest rising occurrences of high cloud in regions of deep convection with larger extension over West Africa in summer, and hence of ascent motions in the ITCZ portion concerned by the monsoon circulation (Fig. 5d,e). This raises obviously the question whether these signals are consistent with changes in the West African Monsoon system.

\section{Recent trends in location and intensity of basic West African Monsoon descriptors}

\subsection{ITCZ and northern subtropical subsidence}

To quantify possible shifts with finer resolution than the basic $2.5^{\circ} \times 2.5^{\circ}$ OLR grid on a monthly basis, we averaged the latitudinal locations of OLR values $<200 \mathrm{~W} / \mathrm{m} 2$ (linked to deep convection in the Tropics). Since air ascents within the ITCZ and air subsidence in the northern subtropics are dynamically linked to the overturning circulation, an OLR-based index has been also defined for describing the latitudinal location of subsidence in the Northern cell. The locations of the poleward edges of the Hadley circulation are first defined as the most poleward latitudes where the OLR equals $250 \mathrm{~W} \mathrm{~m}-2$ because of the dryness of the troposphere and lack of high clouds as in $\mathrm{Hu}$ and $\mathrm{Fu}$ (2007).

The interannual variability of the latitudinal position of convection within the ITCZ and of subsidence branch in the Northern Hemisphere are presented in figures 6 and 7 respectively, for different months and African windows. The significant linear trends at $\mathrm{p}=0.1$ (90\%) are superimposed (see the captions for more details).

There is evidence of a more marked poleward migration of deep convective maximums during the different African rainy seasons: during the tropical rainy season, in July-August, one can notice a $+1.5^{\circ}-2^{\circ}$ shift in latitude (figure $6 \mathrm{c}, \mathrm{d}$ ) northward to $6^{\circ} \mathrm{N}$ and between $15^{\circ} \mathrm{W}$ and $15^{\circ} \mathrm{E}$; similar observations can be made east of $15^{\circ} \mathrm{E}$ of longitude and south of $6^{\circ} \mathrm{N}$ of latitude in May and August-October. By contrast the subsiding branch in the northern overturning does not register any significant shift between $30^{\circ} \mathrm{W}$ and $30^{\circ} \mathrm{E}$ except an apparent equatorward displacement in August of the latitude where the OLR equals $250 \mathrm{~W} \mathrm{m-}$ $2\left(-1.5^{\circ}\right.$ lat, Fig. $\left.7 d\right)$. This could indicate either a possible retraction of the Hadley cell or, more probably, a widening and/or intensification of its subsiding branch in August. This has not been previously reported and differs from what has been observed on a yearly basis and 
for the global Tropics by $\mathrm{Hu}$ and Fu (2007) or Lu et al. ( 2007): former authors document a poleward expansion of the Hadley circulation since 1979 while later stress on its widening in climate change simulations (increasing greenhouse gas scenarios).

Table 1 and 2 enable us to quantify better the above signals. Table 1 allows comparison between African longitudes and the whole Tropics on a yearly basis. The northward shift of the northern overturning circulation and of ITCZ location are attested everywhere when all months are considered whereas changes in ITCZ intensity depend on the region considered: in the western hemisphere the trend is rather low $(-0.5 \mathrm{~W} / \mathrm{m} 2)$ while in African monsoon longitudes these scores equal $-1.3 \mathrm{~W} / \mathrm{m} 2$ in magnitude (Table1). This is also in accordance with figure 4 where long-term changes concentrate over the monsoon domain in association with the poleward migration of deep convection.

Table 2 gives more details arranged by seasons and months for African longitudes. If the northward trends in ITCZ location is clearly attested, a more complex behavior is registered with the branch of subsidence of the northern overturning circulation (NOC): NOC registers poleward displacement in boreal fall, winter and spring $\left(+2.4^{\circ}\right.$ in JFM) but a shift towards the equator in boreal summer $\left(-0.7^{\circ}\right.$ in JAS with $-1.2^{\circ}$ for the sole month of August). This suggests possible alterations of meridional cell overturning (i.e., Hadley-type circulations) at larger scale, a question that we address in next section through mass-flux calculation.

\subsection{Meridional cells}

The mass flux, $\boldsymbol{\Phi}$, is defined as the mass, $d m$, flowing across the unit surface, $d S$, in the unit time, $d t, \boldsymbol{\Phi}=d m /(d t d S) \boldsymbol{n}=\rho \boldsymbol{V}$, where $\boldsymbol{n}$ is the unit vector orthogonal to the unit surface, $\rho$ is the air density and $\boldsymbol{V}$ is the vector wind. The air density $\rho$ is computed using the relationship with the air temperature, $T$, at the pressure level $p: \rho=p M /(R T)$, where $R=$ $8.314 \mathrm{~J} /(\mathrm{mol} \mathrm{K})$ is the universal gas constant, and $M=0.029 \mathrm{~kg} / \mathrm{mol}$ is the molar mass of dry air.

Figure $8 \mathrm{a}, \mathrm{b}$ displays the results along the meridional/vertical plane after computation between the 1000 and $50 \mathrm{hPa}$ levels from $30^{\circ} \mathrm{W}$ to $30^{\circ} \mathrm{E}$ for the northern winter (JanuaryMarch) and summer (July-September) seasons (see the caption for more details). Mean circulations express the well known seasonal changes in cell overturning, i.e., a clear intensification of the winter cell with common ascents located by $5^{\circ} \mathrm{S}\left(8^{\circ} \mathrm{N}\right)$ in $\mathrm{JFM}(\mathrm{JAS})$. 
Figure 8b,d (right diagrams) presents the composite differences defined between the sub-periods 1994-2008 and 1979-1993 in order to test whether changes with time can be considered as significant. The results reveal an unambiguous reorganization of the circulation with significant meridional shift of vertical branches in recent years. In JFM (Fig. 8b) the ascending branch between the southern and northern cells has migrated northward while the northern subsiding branch is reinforced in the higher levels, up to $400 \mathrm{hPa}$. Also note that (i) ascending motions linked to the ITCZ in JAS shift northward, (ii) the southern subsidence between $15^{\circ} \mathrm{S}$ and $30^{\circ} \mathrm{S}$ is stronger whereas, in the northern hemisphere, (iii) the subsidence increases in the highest levels (up to $300 \mathrm{hPa}$ ), as seen in figure 8d. This is coherent with the result of the figure $7 \mathrm{~d}$ and Table 2 .

\subsection{The African heat low}

The African heat low is a main component of the West African Monsoon likely to play a significant role in the rainfall variability because it tends to modulate the monsoon flux and Harmattan winds, i.e. hot, dry and dusty West African trade wind blowing from the northeast or east in the western Sahara (Lavaysse et al., 2008). In particular it favours the monsoon northward penetration through its temperature and humidity budget since warmer low levels and/or more moist mid-levels in the heat low favor a more northerly position of the ITCZ (Peyrille and Lafore, 2007a,b). It can be defined as the continental depression associated with potential temperature increase.

A few indices have been computed for monitoring this centre of action in terms of geographic location (latitude, longitude) and intensity through two spatial indices: (i) a 'Layer Thickness' index (LT, Figure 9 left) based on the gpm height maximums observed in the 700-925 hPa layer over Africa, according to Lavaysse et al. (2008); and (ii) a 'Surface Temperature' index (ST, expressed in ${ }^{\circ} \mathrm{C}$ ) based on surface temperature maximums for diagnosing more directly thermal forcing from the continental surface.

Time evolutions of these indices for the April-October months of periods 1979-1992 and 1993-2006 show strong positive correlations between LT (at left) and ST (figure 9 at right). This relationship can be simply described: during spring, the heat low migrates towards North and West (Fig. 9a-d) and intensifies (Fig. 9e-f) before withdrawing in the reverse direction in fall. This movement is concomitant of the northward excursion of the monsoon circulation and associated rainbelt. The heat low reaches therefore its utmost position and strength at the peak of the Sahelian rainy season in July-August $\left(27^{\circ} \mathrm{N}, 2.5^{\circ} \mathrm{W}, 2440 \mathrm{gpm}\right.$ for 
LT; $25^{\circ} \mathrm{N}, 7-10^{\circ} \mathrm{W}, 36^{\circ} \mathrm{C}$ for ST) though variations in ST longitudinal location can be larger in June around the date of monsoon onset (Fig 9b,d).

The significant differences (asters) registered between the 2 half periods are displayed in all panels. They show that in June-July the LT index extends more northward and westward during the recent period than before $\left(+1^{\circ}\right.$ or $2^{\circ}$ in latitude; -1 or $-2^{\circ}$ in longitude, Fig. $\left.9 a, c\right)$ and reinforces after July (+ 10 gpm, Fig. 9e). Its observed interannual variability cannot be interpreted in terms of linear trends since changes with time in the heat low latitudinal location and intensity (Fig. 10a,c) are more due to a rapid change around years 1993-1994 than to a real long-term trend; in contrast ST longitudinal locations present clear negative trends all over the period (Fig. 10b).

\subsection{Surface and low tropospheric fields}

In order to better discuss the results presented above, selected means, composite fields and regional indices are presented in figures 11-13 for the summer period.

Bi-monthly means and composites of Mean Sea Level Pressure (MSLP) are displayed in figure 11a-c and figure 11d-f, respectively while figure $11 \mathrm{~g}-\mathrm{i}$ refer to the interannual evolutions observed over three key-regions: the heat low region (HLR), the Mediterranean (MED) and the Sahel (SAH). Notice that MSLP tends to decrease above these three areas over the period 1979-2006, especially at the end of the Sahelian rainy season in SeptemberOctober (Fig. 11e,h). Moreover a large and significant warming over the northern tropical Atlantic, the Mediterranean and the hot Saharan-Arabian region is depicted in figure 12a,b (shadings). This warming might therefore promote the lower surface pressures viewed in figure 11. In particular, a hotter Western Sahara could induce a deeper heat low favorable to a more efficient monsoon season because decreasing surface pressures over warmer land areas increase the land-ocean temperature contrasts and hence the monsoon circulation.

Moreover, despite a significant vanishing of ascents over the horn of Africa, upward motions in mid and upper troposphere are also enhanced in last years as previously suggested by the significant decrease in OLR over the western and central parts of North Africa (Fig 5d). This is also consistent with the strengthening of westerly and southwesterly anomalies near the surface in the African monsoon region (Fig. 12f). This intensification, attested at 850 $\mathrm{hPa}$ (Fig.13f) as well, affects then a large part of the monsoon layer, as the anticyclonic pattern (Fig. 13d,f) installed above the significant warming in West Sahara (figures 12b).

In mid-troposphere the African Easterly Jet (AEJ, by $15^{\circ} \mathrm{N}$ in Fig. 13c), is mainly linked to the temperature contrasts in low levels between the Sahara and the Guinea coast 
(Fig. 12a). A poleward migration of the jet with time is attested in Figure 13d: the easterly wind differences northward to $15^{\circ} \mathrm{N}$ tend to favor deeper convection southward to this latitude as illustrated by the negative differences in omega (Fig. 12d, green shadings).

In upper levels, (Fig. 13b) significant northeasterly differences, opposed to the mean southwest circulation blowing towards the eastern Mediterranean and Turkey, are seen in figure 13a. Notice also the reinforcement of the divergence in high levels, i.e., the region where the vectors are directed toward either South Atlantic or the Indian Ocean: this slows down the Tropical Easterly Jet (TEJ) over East Africa and India but reinforces the jet in West Africa (Fig. 13a,b by $5^{\circ} \mathrm{N}-15^{\circ} \mathrm{N}$ ), where more vigorous ascents are also diagnosed in recent years (green shadings, Fig. 12d). Such features are globally coherent with rainfall changes since TEJ strengthening is known to be associated with anomalous wet years in the Sahel (Newell and Kidson 1984; Fontaine et al. 1995) and upward motion on the southern flank of the AEJ (Grist and Nicholson, 2001).

\section{Discussion}

The above results show that growing rainfall amounts observed since the mid-90s have been accompanied in boreal summer by a northward migration of isohyets, an intensification and a poleward migration of deep convective maxima in July-August consistent with changes in cell circulation over Africa in the meridional plane. What are the assumptions that could be explain part of these signals?

\subsection{Global warming}

The first one is an open discussion and concerns the existence of possible links with long-term warming. Mitas and Clement [2005] for example have shown that the boreal winter Hadley cell in reanalyses (NCEP/NCAR and ERA40) has increased in strength by as much as $30 \%$ over the last half-century. This raises the question of its concomitance with global warming and therefore the need to check through model outputs. However when the same authors use 22 coupled models forced with historical changes in greenhouse gases and 12 atmospheric models forced by Sea Surface Temperatures (SSTs) and sea-ice distribution prescribed from the observational record, they observe a decrease, or no increase of the boreal winter Hadley cell strength in the models. They conclude thus that "it is unclear what is the true long-term behavior of the Hadley cell”. More recently Lu et al. (2007) and Hu and Fu 
(2007) have nevertheless suggested that due to long-term warming the meridional extent of tropical overturning (Hadley cells) should expand with time.

Paethe and Hense (2004), have also implied greenhouse-gas driven signals, showing that the partial amelioration of the Sahel drought may be a sign of a long-term increase in rainfall. On the other hand, Christensen et al. (2007) tempered this assumption, arguing that it is unclear how rainfall in the Sahel, the Guinean Coast and the southern Sahara will evolve in the future. In other words, it is premature to conclude that global warming exerts a positive forcing on the African monsoon since climate models generate disparate responses in those regions, mainly due to biases in the simulations of African climate.

\subsection{Changes in Sea Surface Temperature, aerosols and vegetation}

A few authors involved also the role of sea surface temperatures in the Atlantic, Pacific, and Indian Oceans. For example, a future wetter Sahel has been conceived as the response to a projected warming of the North Atlantic Ocean compared with the South Atlantic Ocean, and a further warming of the Indian Ocean (Hoerling et al., 2006), due either to a reduction of aerosol loading, or to an oscillation of Atlantic Ocean variability with multidecadal time scale (Maynard et al., 2002; Haarsma et al.,2005; Kamga et al., 2005). This last hypothesis is based on numerical simulations showing that a warm phase of the Atlantic Multidecadal Oscillation index (AMO) tends to strengthen the summer rainfall over Sahel. Notice however that in observations the AMO smoothed time series between years 1975 and 2005, (http://www.esrl.noaa.gov/psd/data/timeseries/AMO/), were continuously increasing from -0.4 to +0.35 , when, by contrast, West Africa successively register the largest abnormal rainfall deficits in the 80 s and the rainfall recovery after the mid-90s.

Using numerical experiments Bader and Latif (2003) provided evidence of anticorrelations between the observed low-pass-filtered rainfall over the West Sahel and tropical Indian Ocean SSTs. They suggested that warming trends in the Indian Ocean played a crucial role for the drying trend over the West Sahel from the 1950s to 1990s, while the tropical Pacific's influence is predominantly over the East Sahel and the tropical Atlantic impacts rainfall only along the Guinea Coast. Unluckily this interesting assumption can not be taken into account to explain the signals shown in previous sections because the simulations do not reproduce exactly the latitudinal displacements in precipitation, convection and air subsidence here reported.

West African regions are also very sensitive to climate feedback processes associated with water vapour and lapse rate, surface albedo or clouds, which all play a critical role: 
Webb et al. (2006) found that regarding the models' estimate of sensitivity, differences in feedbacks contribute almost three times more to the range in equilibrium climate sensitivity estimates than differences in the models' radiative forcings (see also Randall et al., 2007). In particular aerosol feedbacks may act to amplify the ocean-forced component of monsoon circulation. It has been shown for example that dust exports and vegetation loss are thought to account for $30 \%$ and $10 \%$ of the observed Sahel precipitation reduction, respectively (Wilby $\mathrm{R}, 2009$ ). More generally, the direct and the indirect effects of aerosols, affect sea surface temperature (SST) gradients and favour drying at the northern edge of the ITCZ (Biasutti and Giannini, 2006). By contrast the omission of dynamic vegetation in the models tends to moisten the response to SST forcing (Giannini et al., 2003).

\subsection{Mediterranean and Saharan warming.}

This section presents a complementary hypothesis based on the diagnoses presented in section 2,3, which involves the recent warming observed in the northern subtropical deserts, especially around the Mediterranean/Saharan region. Discussing the results of simulations performed by the IPCC consortium in its last report, Christensen et al. (2007) showed first that the warming in these regions is likely robust and largest in summer. Second, they establish that the highest summer temperatures simulated in these regions are likely increasing more than the summer temperature simulated in southern and central Europe. Similarly, over the African continent, the warming is larger than the global annual mean warming throughout the continent and in all seasons, with drier subtropical regions warming more than the moister tropics, as illustrated by the June-August temperature and precipitation changes in figure 14 from the multi-model data set (A1B simulations). It is noteworthy that the simulated warming is larger on the Mediterranean $\left(>3^{\circ} \mathrm{C}\right)$ and in Western Sahara $\left(>4^{\circ} \mathrm{C}\right)$ than on the adjacent Oceans and is associated with more (less) rainfall in northern Sahel (Mediterranean). Such a pattern produces a poleward expansion of the subtropical highs with a tendency for monsoonal circulations to result in increased precipitation due to enhanced moisture convergence (Christensen et al., 2007). Moreover, as pointed out by Haarsma et al. (2005), any increase in surface air temperature over the Sahara, relative to the surrounding oceans, tends to decrease surface pressure over the Sahara, thereby increasing the Sahel rainfall. Using an empirical approach and case studies, Raicich et al. (2003) showed also that the Mediterranean Sea area takes part in the tropical circulation regime which increases during summer in the African region through the low-level branch of the local Hadley cell. 
In our results, the Mediterranean warming is seen significant and robust despite the short period considered. It is also known to exert a significant forcing on the African monsoon activity both on interannual and decadal scales, as reported in numerical experiments (Rowell, 2003; Peyrillé et al., 2007a,b, Fontaine et al., 2009).

This can be illustrated through the atmospheric response to thermal Mediterranean forcing in terms of zonal and meridional water fluxes through model outputs issued from April-September simulations performed on the ARPEGE-Climat model by the AMMA community. This set of experiments has been chosen because it makes available 20 control simulations (climatology), 20 cold and 20 warm simulations with abnormally cold and warm SST conditions in the Mediterranean. Briefly the cold and warm simulations correspond to a thermal forcing defined through observed SST canonical correlation analyses and only added over the Mediterranean: the boundary conditions over all other seas and Oceans (Atlantic, Indian, Pacific) were the climatology observed. SST conditions have then been prescribed with these anomaly patterns added to the climatology of observed SST (see Fontaine et al., 2009 for more details).

Figure 15 a,b presents the zonal and meridional mean moisture fluxes averaged between $20^{\circ} \mathrm{W}$ and $30^{\circ} \mathrm{E}$ in the low and mid tropospheric layers. The moisture transport is seen with a SW maximum at $925 \mathrm{hPa}$ by $10^{\circ} \mathrm{N}$ (positive values in panels a,b) and an easterly maximum at $700 \mathrm{hPa}$ around $10^{\circ} \mathrm{N}$, hence just under and southward to the main AEJ axis, as shown by the negative values in Fig 15a. Warm minus control composites in figure 15e,f portray larger significant signals. In particular the zonal moisture transport by the AEJ is shifted northward (negative/positive dipolar patterns at $700 \mathrm{hPa}$ in figure 15e) while in lower levels, negative/positive differences northward/southward to $20^{\circ} \mathrm{N}$ in figure $15 \mathrm{e}, \mathrm{f}$ reveal a significant increase of the southwest monsoon, which augments moisture convergence in low levels. This is close to most long-term trends in intensity and latitudinal location reported in previous sections.

\section{Summary}

This study aimed at quantifying changes with time over the African monsoon region in terms of precipitation, OLR and atmospheric variables or indices, and at discussing the results. The recent rainfall increase, already depicted in the Sahelian region by a few authors has been first verified. Our study shows that such growing amounts are mainly observable since the mid-90s but cannot be interpreted in simple terms of linear trends. They have been also accompanied by a northward migration of isohyets, i.e., $+1.5^{\circ}$ for the $400 \mathrm{~mm}$ isoline in 
July-September for the most part significant between $0^{\circ}$ and $30^{\circ} \mathrm{E}$. This is associated with two features: (i) an intensification and a poleward migration of deep convective maxima in JulyAugust, enhanced between $15^{\circ} \mathrm{W}$ and $15^{\circ} \mathrm{E}$, i.e., $+1.5^{\circ}-2^{\circ}$ in latitude, $-1.3 \mathrm{~W} / \mathrm{m} 2$ in OLR; (ii) an apparent southward shift of the southern border of the northern subsidence branch by about $-1^{\circ}$ in northern summer $\left(-1.5^{\circ}\right.$, in August). Undeniably all changes are more marked in August. At larger scale an unambiguous reorganization of the overturning circulation has been noticed in the meridional cell overturning as well, i.e., increasing subsidence in high troposphere over the Mediterranean and increasing ascendance accompanied by a significant northward shift of the vertical branch close to the African ITCZ in northern summer.

In recent years (after 1993-94), the migration of the Saharan heat low towards North West has been more marked $\left(+1^{\circ}\right.$ or $2^{\circ}$ in latitude; -1 or $-2^{\circ}$ in longitude) while its centre intensified at the peak of the tropical rainy season (+ 10 gpm thickness in the 700-925 $\mathrm{hPa}$ layer). This was accompanied by a reinforced monsoon circulation with stronger SW winds in low levels, stronger TEJ in the upper troposphere, an AEJ axis displaced poleward favoring enhanced convection South of its main axis and enabling this convection to move towards the North. Analysis of ARPEGE-climat model simulations forced by SST anomalies in the Mediterranean basin and multi-model outputs from IPCC shows that part of these changes could be due to the warming observed in the Mediterranean region and Sahara.

Acknowledgements: The authors are grateful to the NOAA-CIRES ESRL/PSD Climate Diagnostics branch, to the NCEP/DOE2 community and to the CNRM team for providing OLR data, atmospheric reanalyses and ARPEGE-climat outputs. M. Gaetani thanks also G.A. Dalu for useful discussion. The study was supported by the TELEMEDAF (Italian CNR / French CNRS Joint project), the Global change and Ecosystems programme (EU Integrated project: African Monsoon Multidisciplinary Analysis (AMMA) and the French component of AMMA. Based on a French initiative, AMMA was built by an international scientific group and is currently funded by a large number of agencies, especially from France, UK, US and Africa. Detailed information on scientific coordination and funding is available on the AMMA International web site http://www.amma-international.org 


\section{Tables}

\begin{tabular}{|c|c|c|c|}
\hline Trend & $\begin{array}{c}\text { WesternTropics } \\
{\left[180^{\circ} \mathrm{W}-30^{\circ} \mathrm{W}\right]}\end{array}$ & $\begin{array}{c}\text { West Africa } \\
{\left[30^{\circ} \mathrm{W}-30^{\circ} \mathrm{E}\right]}\end{array}$ & $\begin{array}{c}\text { Eastern Tropics } \\
{\left[30^{\circ} \mathrm{E}-180^{\circ} \mathrm{E}\right]}\end{array}$ \\
\hline $\mathrm{NOC}\left({ }^{\circ}\right.$ lat $)$ & +1.3 & +0.9 & +0.8 \\
\hline ITCZ $\left({ }^{\circ}\right.$ lat $)$ & +0.5 & +0.5 & +0.8 \\
\hline$I T C Z(\mathrm{~W} / \mathrm{m} 2)$ & -0.5 & -1.3 & -1.1 \\
\hline
\end{tabular}

Table 1: Long-term evolution of the subsidence branch of the northern overturning circulation (NOC), ITCZ position (in ${ }^{\circ}$ lat), ITCZ intensity, over three longitudinal windows and the period 1979-2007. All months are considered.

\begin{tabular}{|l|l|l|l|l|l|l|l|l|l|l|}
\hline $\begin{array}{l}\text { Trend } \\
{\left[30^{\circ} \mathrm{W}-\right.} \\
\left.30^{\circ} \mathrm{E}\right]\end{array}$ & JFM & AMJ & JAS & OND & MAY & JUN & JUL & AUG & SEP & OCT \\
\hline NOC [ ${ }^{\circ}$ lat $)$ & +2.4 & +0.8 & -0.7 & +1.2 & +0.7 & -0.2 & -0.8 & -1.2 & -0.7 & +0.2 \\
\hline ITCZ $\left({ }^{\circ}\right.$ lat) & 0 & +0.6 & +0.9 & +0.4 & +0.7 & +0.4 & +0.8 & +1.3 & +0.8 & +1.3 \\
\hline
\end{tabular}

Table 2: As table 1 but with a seasonal and monthly (in italic) basis and for the $30^{\circ} \mathrm{W}-30^{\circ} \mathrm{E}$ window. 


\section{References}

Bader J, Latif M., 2003. The impact of decadal-scale Indian Ocean sea surface temperature anomalies on Sahelian rainfall and the North Atlantic Oscillation, Geopys. Res. Letters, 30, 22, 2169, doi:10.1029/2003GL018426

Biasutti, M., and A. Giannini, 2006: Robust Sahel drying in response to late 20th century forcings. Geophys. Res. Lett., 33, L11706, doi:10.1029/ 2006 GRL026067.

Chen JY, Carlson BE, Del Genio AD. 2002. Evidence for strengthening of the tropical general circulation in the 1990s, Science, 295, 838-841

Christensen, JH, B Hewitson, A Busuioc, A Chen, X Gao, I Held, R Jones, RK Kolli, W-T Kwon, R Laprise, V Magaña Rueda, L Mearns, CG Menéndez, J Räisänen, A Rinke, A Sarr and P Whetton. 2007. Regional Climate Projections. In: Climate Change 2007: The Physical Science Basis. Contribution of Working Group I to the Fourth Assessment Report of the Intergovernmental Panel on Climate Change [Solomon, S., D. Qin, M. Manning, Z. Chen, M. Marquis, K.B. Averyt, M. Tignor and H.L. Miller (eds.)]. Cambridge University, Press, Cambridge, United Kingdom and New York, NY, USA.

Dai Lamb PJ, Trenberth KE, Hulme M, Jones PD, Xie P. 2004. The recent Sahel drought is real, International Journal of Climatology 24, 1323-1331

D'Amato N, T. Lebel, 1998. On the characteristics of the rainfall events in the sahel with a view to the analysis of climatic variability. Int. J. Climatol., 18, 955-974.

Fontaine B, Garcia J, Roucou P, Rodriguez-Fonseca MB, Sivarajan S, Gervois S, Chauvin F, Ruti P, Janicot S. 2009. Impacts of Warm and Cold situations in the Mediterranean Basins on the West African monsoon: observed connection patterns (19792006) and climate simulations, Climate Dynamics, ISSN0930-7575 (Print) 1432-0894 (Online), published online 11 June 2009, DOI 10.1007/s00382-009-0599-3

Fontaine B, Janicot S, Moron V. 1995. Rainfall anomaly patterns and wind field signals over West Africa in August (1958-1989), J. of Climate, 8, 6, 1503-1510, 1995

Giannini A Biasutti M, Verstraete MM, 2008, A climate model-based review of drought in the Sahel: Desertification, the re-greening and climate change, Global and Planetary Change, Volume 64, Issues 3-4, ,119-128, Climate Change and Desertification

Giannini, A., R. Saravanan, and P. Chang, 2003: Oceanic forcing of Sahel rainfall on interannual to interdecadal time scales. Science, 302, 1027-1030.

Grist, JP, Nicholson SE. 2001. A Study of the Dynamic Factors Influencing the Rainfall Variability in the West African Sahel. , J. of Climate, 14, 1337-1359, 2001.

Haarsma, R.J., F. Selten, N. Weber and M. Kliphuis, Sahel rainfall variability and response to greenhouse warming, Geophys. Res. Lett (2005) $\underline{10.1029 / 2005 G L 023232}$. Haarsma et al., 2005). 
Haarsma, RJ, Selten F, Weber S, Kliphuis M. 2005. Sahel rainfall variability and response to greenhouse warming. Geophys. Res. Lett., 32, L17702, doi:10.1029/2005GL023232

Hoerling, M.P., J.W. Hurrell, and J. Eischeid, 2006: Detection and attribution of 20th century Northern and Southern African monsoon change. J. Clim. 19(16), 3989-4008.

$\mathrm{Hu}$ Y, Fu Q. 2007. Observed poleward expansion of the Hadley circulation since 1979, Atmos. Chem. Phys., 7, 5229-5236

Kamga, A.F., et al., 2005: Evaluating the National Center for Atmospheric Research climate system model over West Africa: Present-day and the 21 st century A1 scenario. J. Geophys. Res., 110(D03106), doi:10.1029/2004JD004689.

Lau KM, Wu HT. 2007. Detecting trends in tropical rainfall characteristics, 19792003, Int. J. Climatol. 27: 979-988 DOI: 10.1002/joc.1454

Lavaysse C, Flamand C, Janicot S. 2008. Impacts of the intra-seasonal oscillations of West African Heat Low over the Sahel, Geophysical Research Abstracts, Vol. 10, EGU2008A-10941, 2008.

Le Barbé L, T. Lebel, 1997. Rainfall climatology of the HAPEX-Sahel region during the years 1950-1990. J. Hydrol., 188-189, 43-73.

Lebel T, Ali A. 2008. Recent trends in the Central and Western Sahel rainfall regime (1990 - 2007), submitted for publication in the AMMA-CATCH special issue of Journal of Hydrology 13 Revised Version - September 2008.

Lebel T, JD Taupin, N. D'Amato, 1997. Rainfall monitoring during HAPEX-Sahel. 1. General rainfall conditions and climatology. J. Hydrol., 188-189, 74-96.

Liebmann B, Smith CA. 1996. Description of a Complete (Interpolated) Outgoing Longwave Radiation Dataset. Bulletin of the American Meteorological Society, 77, 12751277

Lu J, Vecchi GA., Reichler T. 2007. Expansion of the Hadley cell under global warming, Geophys. Res. Lett., 34, L06805, doi:10.1029/2006GL028443

Maynard, K., J.-F. Royer, and F. Chauvin, 2002: Impact of greenhouse warming on the West African summer monsoon. Clim. Dyn., 19, 499-514.

Mitas CM, Clement A. 2006. Recent behavior of the Hadley cell and tropical thermodynamics in climate models and reanalyses, Geophys. Res. Lett., 33, L01810, doi:10.1029/2005GL024406.

Mitchell TD, Carter TR, Jones PD, Hulme M, New M. 2004. A comprehensive set of high-resolution grids of monthly climate for Europe and the globe: the observed record (19012000) and 16 scenarios (2001-2100). Tyndall Working Paper 55, Tyndall Centre, UEA, Norwich, UK. http://www.tyndall.ac.uk/ 
New M, Lister D, Hulme M, Makin I. 2002. A high-resolution data set of surface climate over global land areas. Climate Research 21: 1-25

Newell RE, Kidson JW. 1984. African mean wind changes in Sahelian wet and dry periods. Int. J. Climatol., 4, 1-7, 1984.

Nicholson S. 2005. Journal of Arid Environments Volume 63, Issue 3, November 2005, Pages 615-641. Special Issue on The "Greening" of the Sahel, doi:10.1016/j.jaridenv.2005.03.004, Elsevier

Paethe H, Hense A.. 2004. SST versus climate change signals in West African rainfall: 20th-century variations and future projections. Clim. Change, 65(1-2): 179-208

Peyrillé P. Lafore JP. 2007. An idealized two-dimensional framework to study the west african monsoon. Part II Large-scale advection and the diurnal cycle, Journal of the atmospheric sciences, 64, $n^{\circ} 8,2783-2803$

Peyrillé P., J. P. Lafore, J. L. Redelsperger, 2007. An idealized two-dimensional framework to study the West African Monsoon. Part I: validation and key controlling factors, J. Atmos. Sci., , 64, 2765-2782.

Raicich F, Pinardi N. Navarra A. 2003. Teleconnections between Indian monsoon and Sahel rainfall and the Mediterranean, Int. J. Climatol. 23: 173-186

Randall, D.A., R.A. Wood, S. Bony, R. Colman, T. Fichefet, J. Fyfe, V. Kattsov, A. Pitman, J. Shukla, J. Srinivasan, R.J. Stouffer, A. Sumi and K.E. Taylor, 2007: Cilmate Models and Their Evaluation. In: Climate Change 2007: The Physical Science Basis. Contribution of York, NY, USA.

Rowell DP. 2003. The Impact of Mediterranean SSTs on the Sahelian Rainfall Season, 16, 849-8610

Solomon S, Qin D, M Manning, RB Alley, T Berntsen, NL Bindoff, Z Chen, A Chidthaisong, JM Gregory, GC Hegerl, M Heimann, B Hewitson, BJ Hoskins, F Joos, J Jouzel, V Kattsov, U Lohmann, T Matsuno, M Molina, N Nicholls, J Overpeck, G Raga, V Ramaswamy, J Ren, M Rusticucci, R Somerville, TF Stocker, P Whetton, RA Wood and D Wratt. 2007. Technical Summary. In: Climate Change 2007: The Physical Science Basis. Contribution of Working Group I to the Fourth Assessment Report of the Intergovernmental Panel on Climate Change [Solomon, S., D. Qin, M. Manning, Z. Chen, M. Marquis, K.B. Averyt, M. Tignor and H.L. Miller (eds.)]. Cambridge University Press, Cambridge, United Kingdom and New York, NY, USA

Webb, M. J.; Senior, C. A.; Sexton, D. M. H.; Ingram, W. J.; Williams, K. D.; Ringer, M. A.; McAvaney, B. J.; Colman, R.; Soden, B. J.; Gudgel, R.; Knutson, T.; Emori, S.; Ogura, T.; Tsushima, Y.; Andronova, N.; Li, B.; Musat, I.; Bony, S.; Taylor, K. E.; (2006). "On the contribution of local feedback mechanisms to the range of climate sensitivity in two GCM ensembles." Climate Dynamics 27, 17-38 : 1-22. <http://hdl.handle.net/2027.42/45863> 
Wilby R, review of recent trends and projected climate changes for Niger, West Africa http://www.worldwaterweek.org/documents/WWW_PDF/Resources/2009_WnC/NigerSS_Technical_Brief_R_Wilby.pdf

Zhao H, Moore and GWK. 2008. Trends in the boreal summer regional Hadley and Walker circulations as expressed in precipitation records from Asia and Africa during the latter half of the $20^{\text {th }}$ century, Int. J. Climatol., 28, 563-578 (2008) DOI: $10.1002 /$ joc. 1580 
Figures captions

Figure 1: Mean and composite rainfall time evolution. (a) evolution of Northern summer monthly rainfall (April to October) between $15^{\circ} \mathrm{W}-30^{\circ} \mathrm{E}$ in North Africa over the period 1979-2002 and composite differences between the 2 half periods 1994-2002 and 1979-1992 for different longitudinal windows: (b) $\left[15^{\circ} \mathrm{W}-30^{\circ} \mathrm{E}\right]$; (c) $\left[15^{\circ} \mathrm{W}-0^{\circ}\right]$; (d) $\left[.0^{\circ}-15^{\circ} \mathrm{E}\right]$; (e) $\left[15^{\circ} \mathrm{E}-30^{\circ} \mathrm{E}\right]$. Blue dashed lines and yellow shadings refer to the significant negative and positive differences at $\mathrm{p}=0.10(90 \%)$ respectively. Units in $\mathrm{mm}$.

Figure 2: Interannual rainfall evolution (1990-2008) in July-September at the seasonal and monthly time scales over the region of Niamey $\left(1.6^{\circ} \mathrm{E}-3.2^{\circ} \mathrm{E} ; 13^{\circ} \mathrm{N}-14^{\circ} \mathrm{N}\right)$. Seasonal and monthly means are indicated in $\mathrm{mm}$. The superimposed linear trend in panel $\mathrm{b}$ is significant at $\mathrm{p}=0.01(99 \%)$ regarding the probability density function of Spearman's rank correlation coefficients, using 20000 resamplings through Monte Carlo simulations.

Figure 3: Interannual and low frequency (> 8 yr) rainfall variability from 1979 to 2002 using regional indices averaged between $5^{\circ} \mathrm{N}$ and $20^{\circ} \mathrm{N}$ : (a) annual (curves at top), July-September (solid lines in middle) and August (dashed at bottom) time evolutions between $15^{\circ} \mathrm{W}$ and $30^{\circ} \mathrm{E}$; (b) annual (top) and July-September (bottom) variations over $15^{\circ} \mathrm{W}-30^{\circ} \mathrm{E}$ (blue), $15^{\circ} \mathrm{W}-0^{\circ}$ (red) and $15^{\circ} \mathrm{E}-30^{\circ} \mathrm{E}$ (green). Values in $\mathrm{mm}$. Curves are bolded when changes between 1984 and 1996 are significant at $\mathrm{p}=0.1$.

Figure 4: Interannual and low frequency ( $>8 \mathrm{yr}$ ) latitudinal variability of specific isohyets from 1979 to 2002 using the same latitudinal windows and colors in figure 3 :

(a) $1000 \mathrm{~mm}$ for annual amounts (solid curves at bottom), $350 \mathrm{~mm}$ for July-September (solid) and $250 \mathrm{~mm}$ for August amounts( dashed at top);

(b) annual isohyet $1000 \mathrm{~mm}$ (curves at bottom) and July-September isohyet $350 \mathrm{~mm}$ (curves at top) over $15^{\circ} \mathrm{W}-30^{\circ} \mathrm{E}$ (blue), $15^{\circ} \mathrm{W}-0^{\circ}$ (red) and $15^{\circ} \mathrm{E}-30^{\circ} \mathrm{E}$ (green). Values in degrees. Curves are bolded when changes between 1984 and 1996 are significant at $\mathrm{p}=0.1$.

Figure 5: Mean bimonthly OLR differences between the 2 half periods 1994-2007 and 19791992 of the period 1979-2007. Red/blue shadings for the significant positive/negative differences at $\mathrm{p}=0.05$.

Figure 6: Interannual variability in the latitudinal location of OLR minima within the ITCZ over the longitudinal windows $15^{\circ} \mathrm{W}-0^{\circ}$ (blue), $0^{\circ}-15^{\circ} \mathrm{E}$ (red) and $15^{\circ} \mathrm{E}-30^{\circ} \mathrm{E}$ (green) and for different months of the period 1979-2007. Linear trends are superimposed when significant at $\mathrm{p}=0.1$ regarding the probability density function of Spearman's rank correlation coefficients, using 2000 resamplings through Monte Carlo simulations.

Figure 7: Interannual and linear trends in latitudinal locations of the poleward edges of the Hadley circulation, defined as the most poleward latitudes where the OLR equals $250 \mathrm{~W} \mathrm{m-2}$ as in $\mathrm{Hu}$ and $\mathrm{Fu}(2007)$ between $30^{\circ} \mathrm{W}$ and $30^{\circ} \mathrm{E}$ and for different months of the period 19792007. Linear trends are superimposed when significant at $p=0.1$ regarding the probability density function of Spearman's rank correlation coefficients, using 2000 resamplings through Monte Carlo simulations. 
Figure 8: $\quad(a, b)$ Latitude-pressure diagram of the meridional/vertical components of the mass flux averaged between $30^{\circ} \mathrm{E}$ and $30^{\circ} \mathrm{W}$ in January-March (a) and July-September (c) 1979-2006. (b,d) composite differences between subperiods 1993-2006 and 1979-1992.

Red arrows indicate Student's t-tests significant at the 5\% level. Contours indicate the magnitude of the vector, the units are in $\mathrm{kg} /\left(\mathrm{m}^{2} * \mathrm{~s}\right)$, contour intevals are 0.3 for the climatology and 0.05 for the anomalies. The vectors are drawn multiplying the vertical component by $10^{4}$.

Figure 9: Mean April-October evolutions of the heat low indices (LT, left and ST, right) at a 5-day time step averaged over the periods 1979-1992 (dashed curves) and 1993-2006 (solid curves) in terms of $(a, b)$ latitudinal and longitudinal $(c, d)$ locations and of strength $(e, f)$. Location in degrees, LT intensity in gpm height, ST intensity in ${ }^{\circ} \mathrm{C}$. The significant composite differences between the 2 periods are marked by asters. The statistical significance has been tested through a Student paired-t-test at $\mathrm{p}=0.05$.

Figure 10: Interannual variability of the Heat low (solid/dashed curves for LT/ST over the period 1979-2006 : (a) latitude in June-July; (b) longitude in June-July; (c) strength in JulyAugust. Location in degrees, LT intensity in gpm height, ST intensity in ${ }^{\circ} \mathrm{C}$.

Figure 11: Mean Sea Level Pressure (MSLP) bi-monthly means (a-c) and [1994-2006] minus [1979-1993] composites (d-f) along with time evolutions of regional indices averaged over selected areas: Mediterranean (MED: $0^{\circ}-30^{\circ} \mathrm{E} ; 30^{\circ} \mathrm{N}-45^{\circ} \mathrm{N}$ ), the Heat Low Region (HLR: $\left.15^{\circ} \mathrm{W}-0^{\circ} ; 20^{\circ} \mathrm{N}-30^{\circ} \mathrm{N}\right)$ and the Sahelian band (SAH: $\left.15^{\circ} \mathrm{W}-30^{\circ} \mathrm{E} ; 10^{\circ} \mathrm{N}-20^{\circ} \mathrm{N}\right)$. The significant composite differences between the 2 periods are marked by shadings. The statistical significance has been tested through a Student paired-t-test at $\mathrm{p}=0.05$.

Figure 12: Surface temperature $\left({ }^{\circ} \mathrm{C}\right)$, omega at $400 \mathrm{hPa}(\mathrm{Pa} / \mathrm{s})$ and wind at $925 \mathrm{hPa}$ (vectors) fields in July-September: mean fields at left and significant composite differences between the two half periods 1994-2007 and 1979-1992 at right. Red (blue) curves for (a) temperatures higher (lower) than $30^{\circ} \mathrm{C}$, isolines varying by $2^{\circ} \mathrm{C}$; (b) positive (negative) temperature differences by $0.5^{\circ} \mathrm{C}$; (c) downward (upward) motion; (d) positive (negative) omega differences; (e) wind at $950 \mathrm{hPa}$; (f) significant wind differences at $950 \mathrm{hPa}$. Shaded areas when temperature $>30^{\circ} \mathrm{C}$ (a), subsidence (b) and the significant composite differences (b,d). The statistical significance has been tested through a Student paired-t-test at $\mathrm{p}=0.05$.

Figure 13: as bottom panels in figure 12 but for the isobaric levels 200, 600 and $850 \mathrm{hPa}$.

Figure 14: Temperature and precipitation changes over Africa from the multi-model data set (A1B simulations). Top: JJA temperature change between 1980 to 1999 and 2080 to 2099, averaged over 21 models. Bottom: same as top, but for fractional change in precipitation (from Christensen et al., 2007. )

Figure 15: Vertical-meridional cross sections between $20^{\circ} \mathrm{W}$ and $30^{\circ} \mathrm{E}$ of mean and composite moisture fluxes from sensitivity experiments on the ARPEGE-Climat Version 3 IPCC-AR4 in truncature 42 with 45 levels run at Centre National de Recherches Météorologiques (see the text for more details).

(a,b) : $\mathrm{u}$ and $\mathrm{v}$ mean components from the 20 April-September control runs; isolines each $5 \mathrm{~m} \mathrm{~s}^{-1} \mathrm{~g} \mathrm{Kg}^{-1}$

c,d (e,f) : composite differences between the 20 cold (20 warm) simulations and 20 control simulations; isolines each $0.5 \mathrm{~m} \mathrm{~s}^{-1} \mathrm{~g} \mathrm{Kg}^{-1}$ 
The solid (dashed) contours refer to the positive (negative) differences. In panels c-f, shadings are superimposed when composite differences are significant at $\mathrm{p}=0.10$ regarding a Student $\mathrm{t}$ test. 
a) Mean rainfall in $\mathrm{mm}$

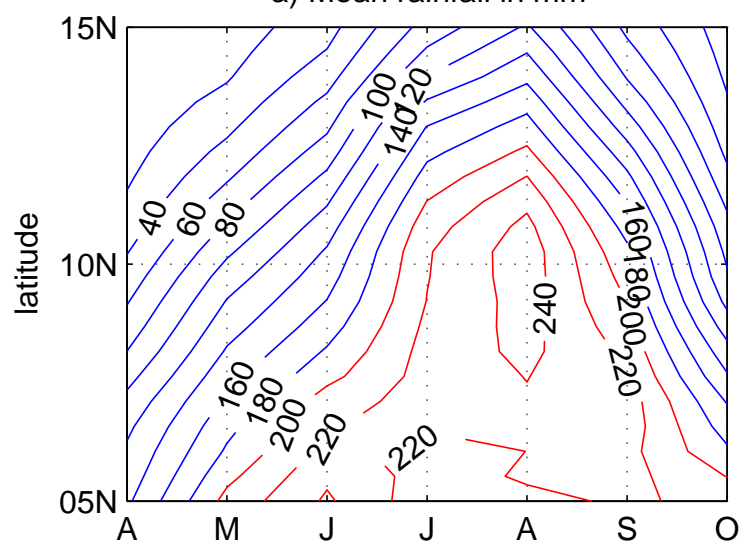

b) Rain diff: 15W-30E

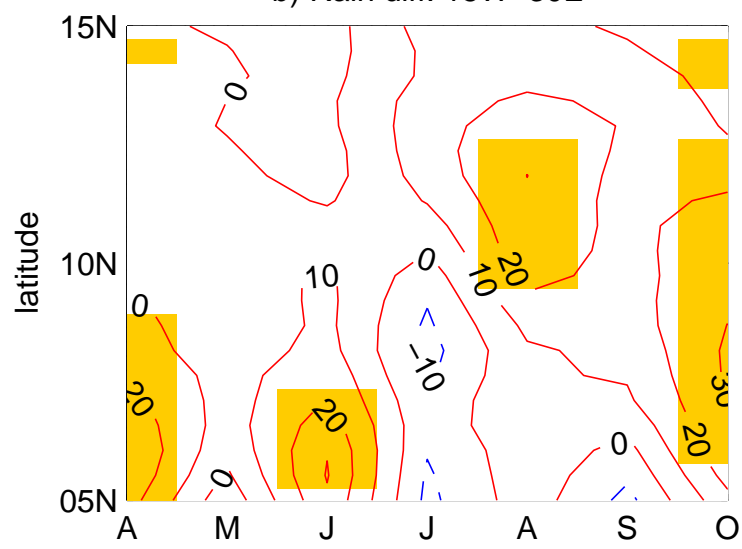

c) Rain diff: $15 \mathrm{~W}-0$

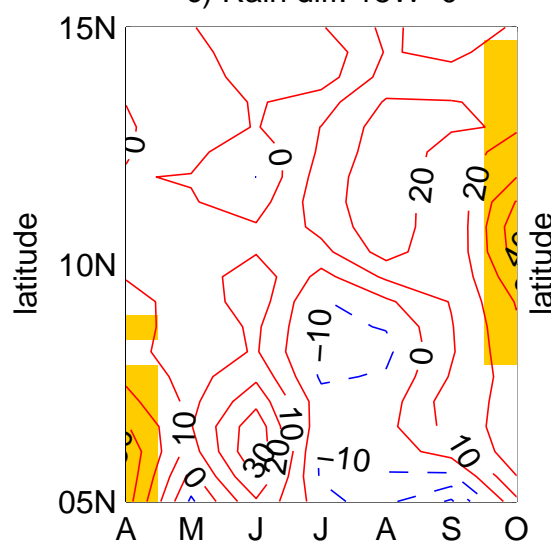

d) Rain diff: 0-15E

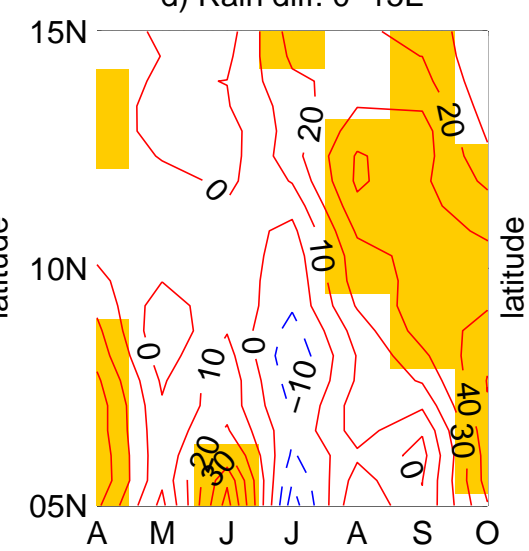

e) Rain diff: 15E-30E

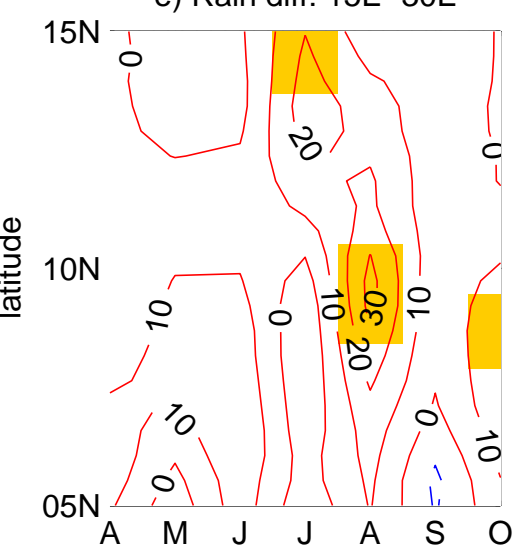

Figure 1: Mean and composite rainfall time evolution. (a) evolution of Northern summer monthly rainfall (April to October) between $15^{\circ} \mathrm{W}-30^{\circ} \mathrm{E}$ in North Africa over the period 1979-2002 and composite differences between the 2 half periods 1994-2002 and 1979-1992 for different longitudinal windows: (b) $\left[15^{\circ} \mathrm{W}-30^{\circ} \mathrm{E}\right]$; (c) $\left[15^{\circ} \mathrm{W}-0^{\circ}\right]$; (d) $\left[.0^{\circ}-15^{\circ} \mathrm{E}\right]$; (e) $\left[15^{\circ} \mathrm{E}-30^{\circ} \mathrm{E}\right]$. Blue dashed lines and yellow shadings refer to the significant negative and positive differences at $\mathrm{p}=0.10(90 \%)$ respectively. Units in $\mathrm{mm}$. 
a) JAS

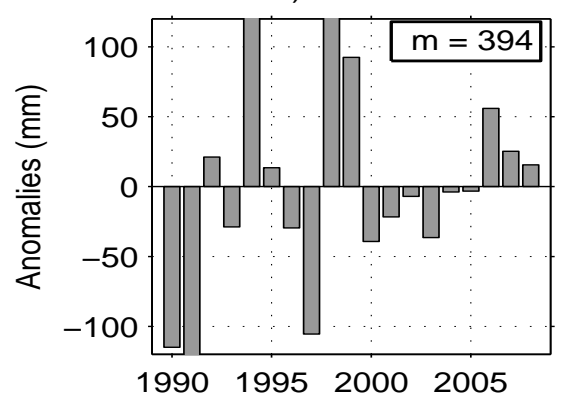

b) July

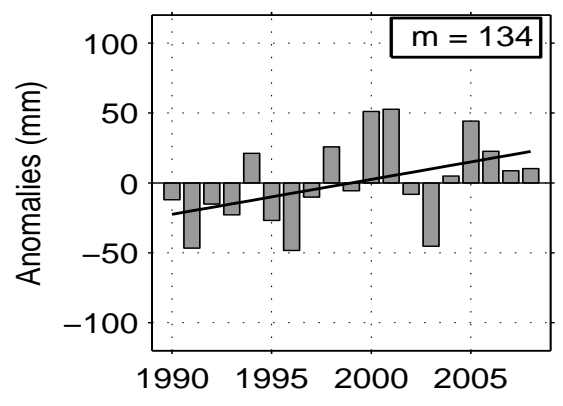

c) August

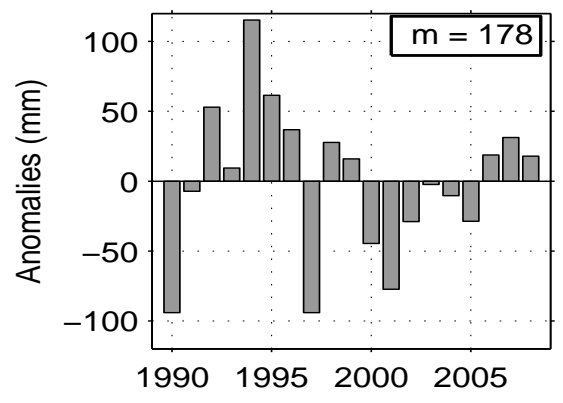

d) September

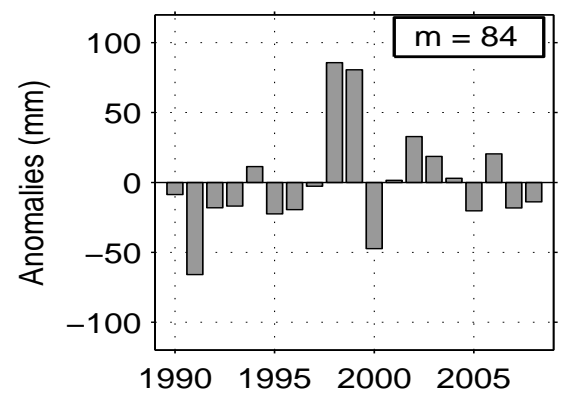

Figure 2: Interannual rainfall evolution (1990-2008) in July-September at the seasonal and monthly time scales over the region of Niamey $\left(1.6^{\circ} \mathrm{E}-3.2^{\circ} \mathrm{E} ; 13^{\circ} \mathrm{N}-14^{\circ} \mathrm{N}\right)$. Seasonal and monthly means are indicated in $\mathrm{mm}$. The superimposed linear trend in panel $\mathrm{b}$ is significant at $\mathrm{p}=0.01(99 \%)$ regarding the probability density function of Spearman's rank correlation coefficients, using 20000 resamplings through Monte Carlo simulations. 
a) Annual,JAS, and Aug rainfall

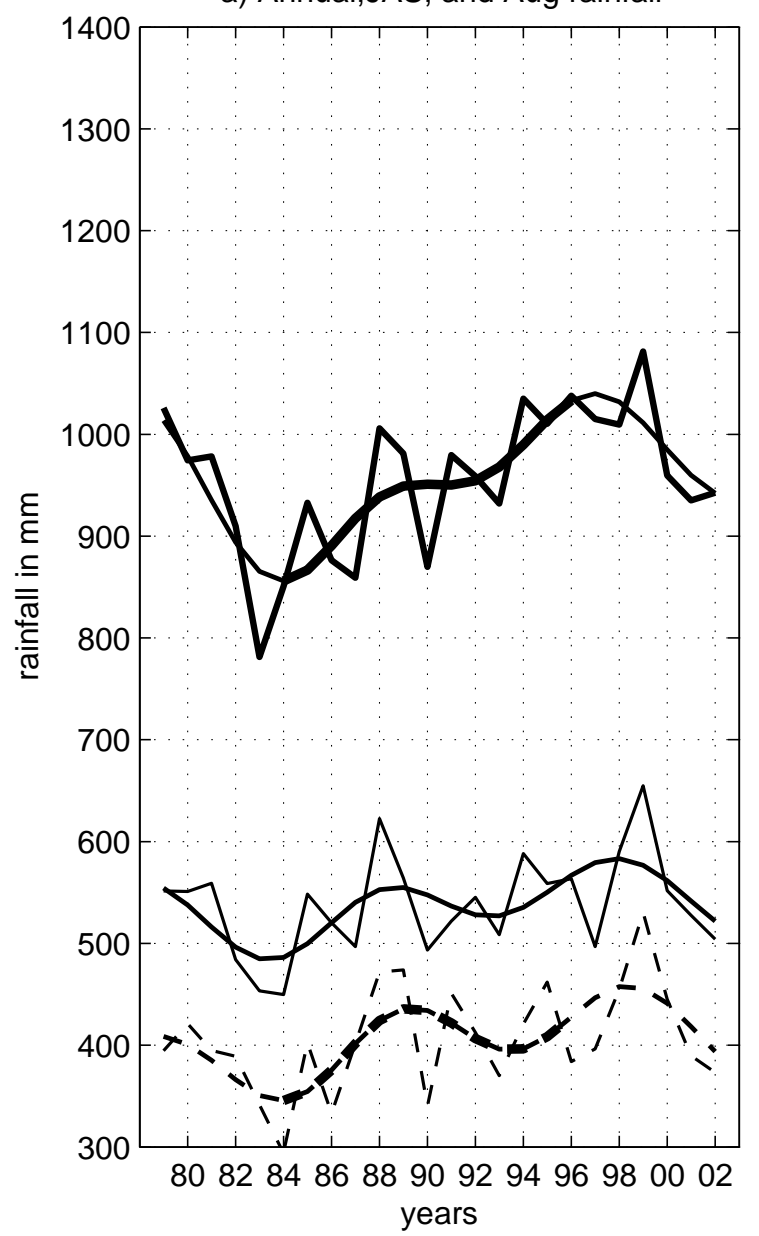

b) West(b), Cent(r), East(g): JAS rainfall

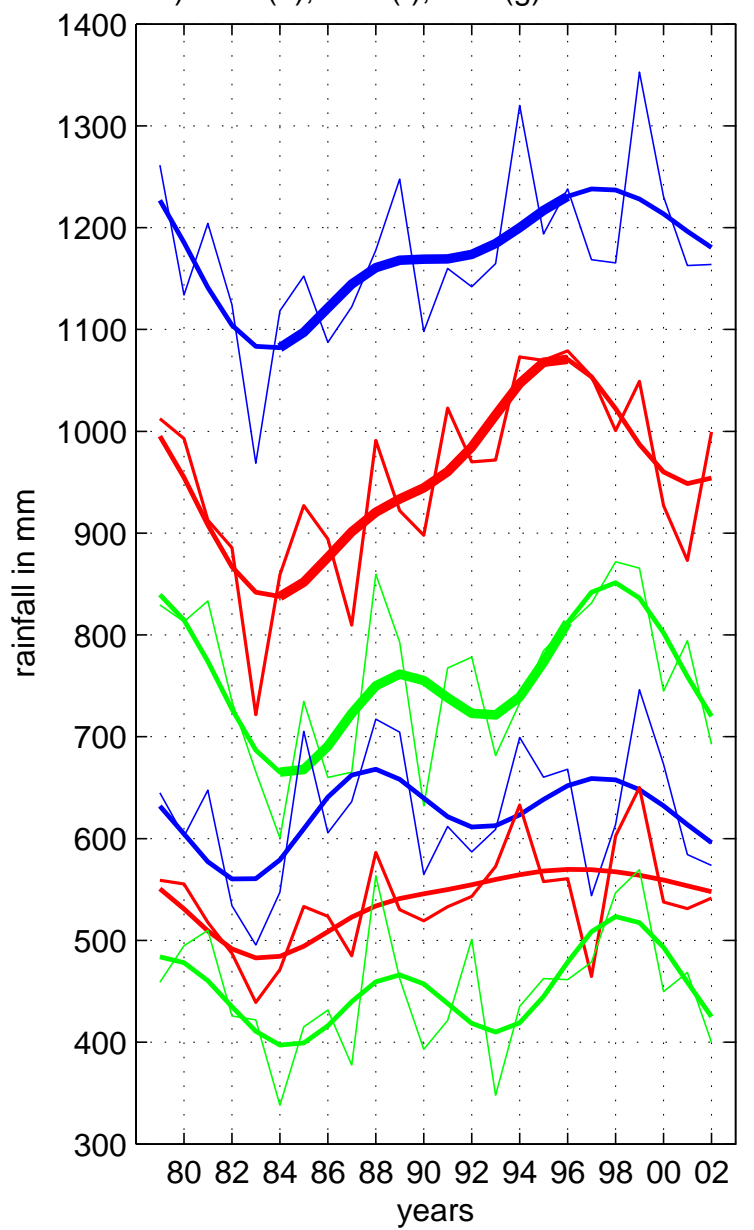

Figure 3: Interannual and low frequency (> 8 yr) rainfall variability from 1979 to 2002 using regional indices averaged between $5^{\circ} \mathrm{N}$ and $20^{\circ} \mathrm{N}$ : (a) annual (curves at top), July-September (solid lines in middle) and August (dashed at bottom) time evolutions between $15^{\circ} \mathrm{W}$ and $30^{\circ} \mathrm{E}$; (b) annual (top) and July-September (bottom) variations over $15^{\circ} \mathrm{W}-30^{\circ} \mathrm{E}$ (blue), $15^{\circ} \mathrm{W}-0^{\circ}$ (red) and $15^{\circ} \mathrm{E}-30^{\circ} \mathrm{E}$ (green). Values in $\mathrm{mm}$. Curves are bolded when changes between 1984 and 1996 are significant at $\mathrm{p}=0.1$. 


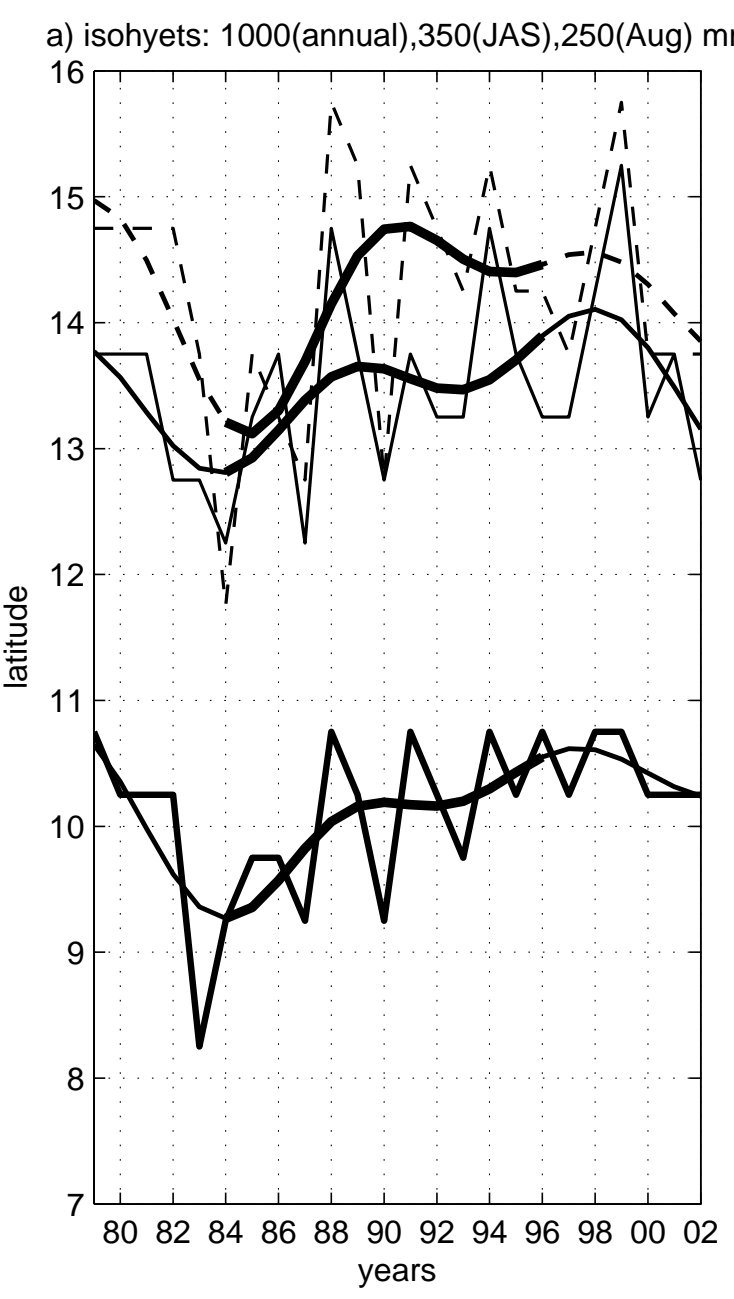

b) West(b), Cent(r), East(g): 1000, 350mm

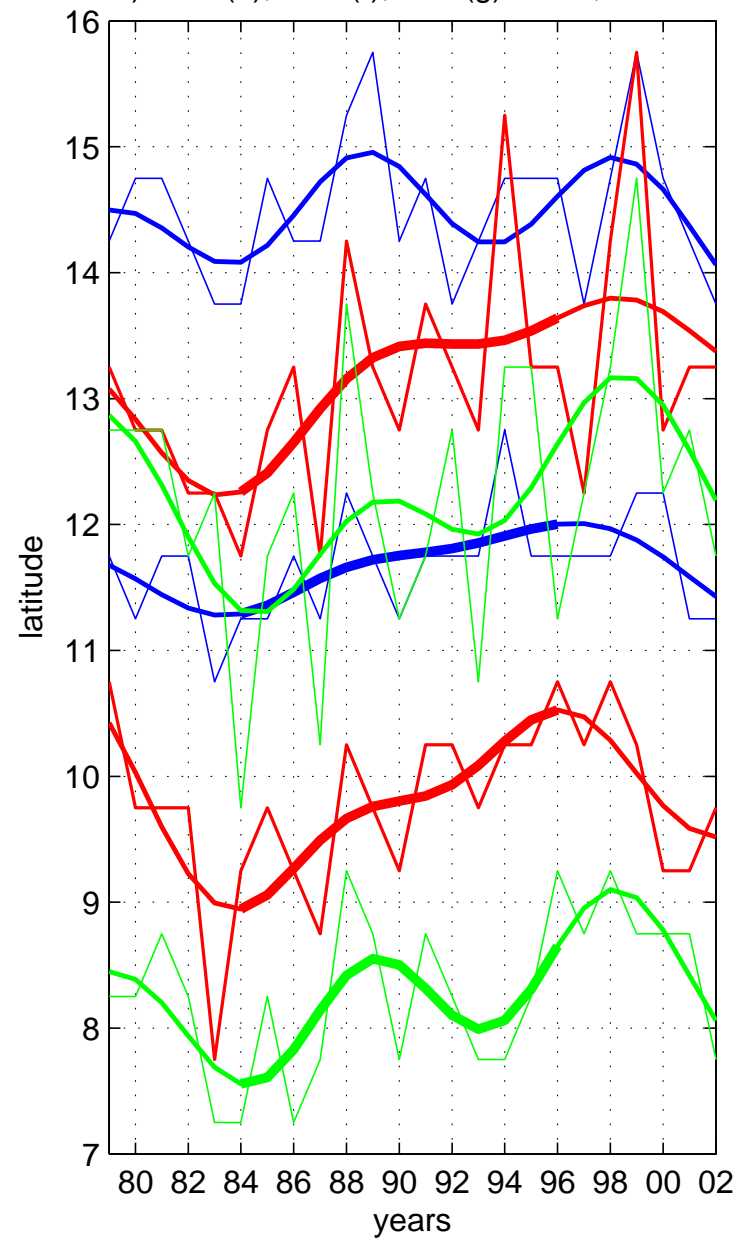

Figure 4: Interannual and low frequency (> $8 \mathrm{yr}$ ) latitudinal variability of specific isohyets from 1979 to 2002 using the same latitudinal windows and colors in figure 3 :

(a) $1000 \mathrm{~mm}$ for annual amounts (solid curves at bottom), $350 \mathrm{~mm}$ for July-September (solid) and $250 \mathrm{~mm}$ for August amounts( dashed at top);

(b) annual isohyet $1000 \mathrm{~mm}$ (curves at bottom) and July-September isohyet $350 \mathrm{~mm}$ (curves at top) over $15^{\circ} \mathrm{W}-30^{\circ} \mathrm{E}$ (blue), $15^{\circ} \mathrm{W}-0^{\circ}$ (red) and $15^{\circ} \mathrm{E}-30^{\circ} \mathrm{E}$ (green). Values in degrees. Curves are bolded when changes between 1984 and 1996 are significant at $\mathrm{p}=0.1$. 
a) JF: OLR trend

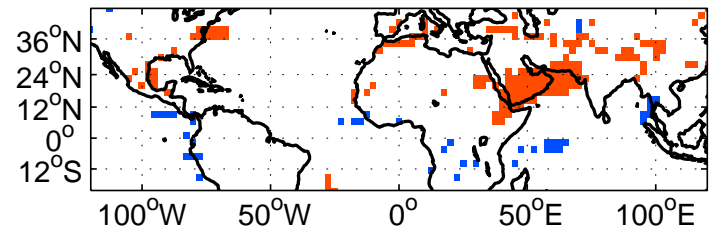

c) MJ: OLR trend

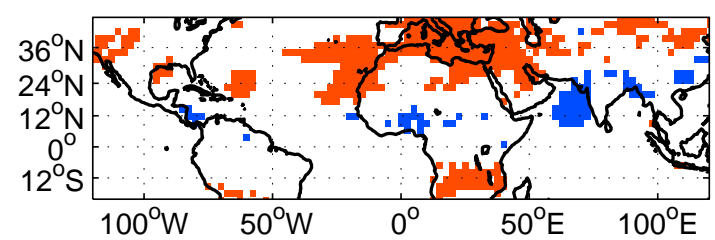

e) SO: OLR trend

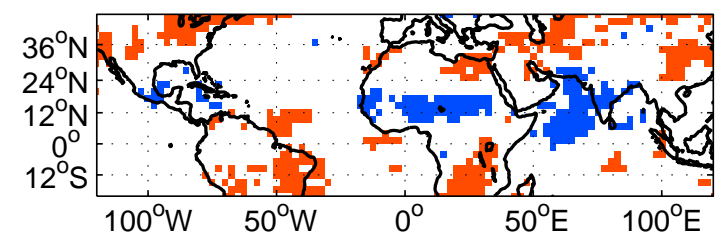

b) MA: OLR trend

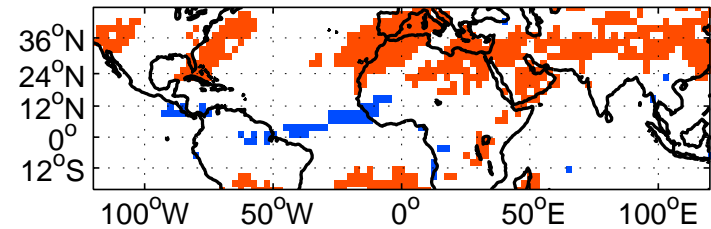

d) JA: OLR trend

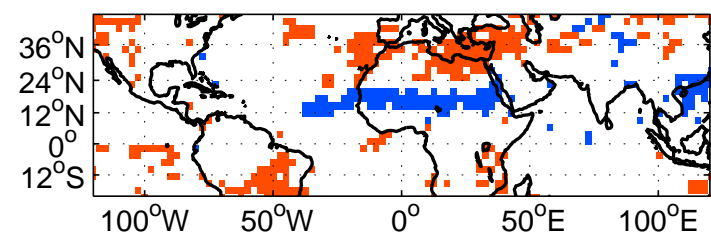

f) ND: OLR trend

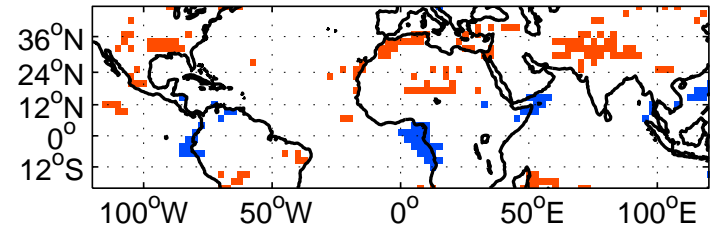

Figure 5: Mean bimonthly OLR differences between the 2 half periods 1994-2007 and 19791992 of the period 1979-2007. Red/blue shadings for the significant positive/negative differences at $\mathrm{p}=0.05$. 
a) MAY

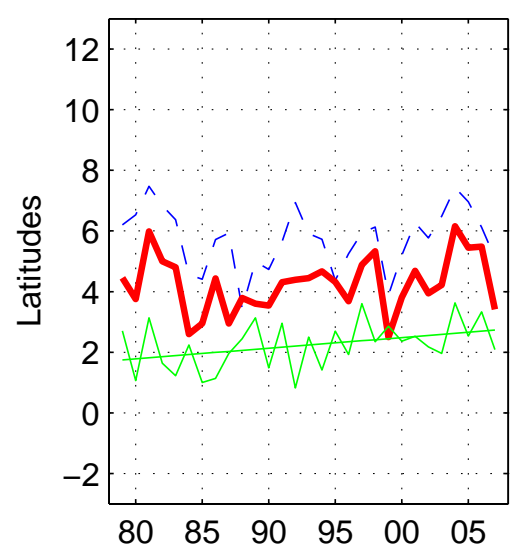

d) $A \cup G$

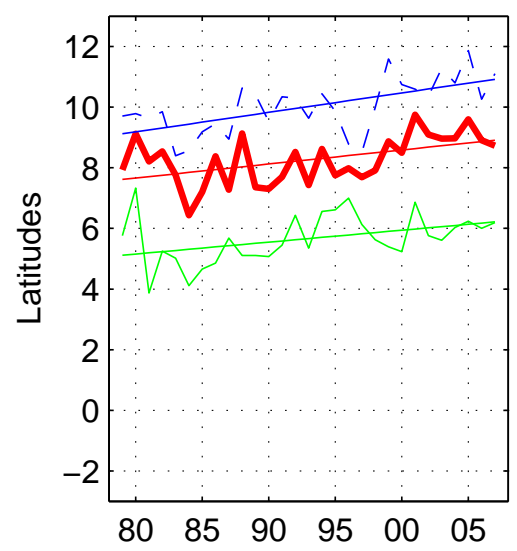

b) JUN

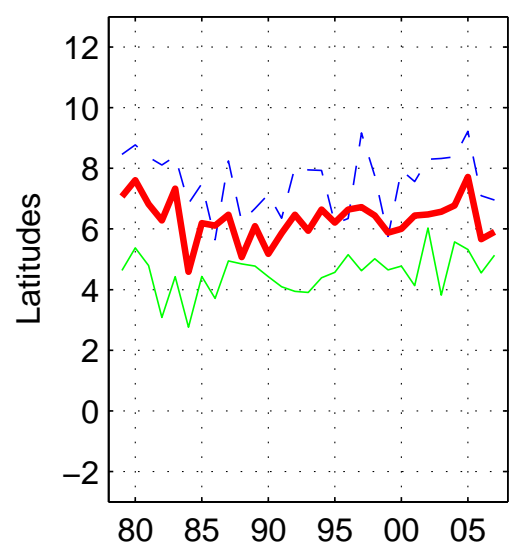

e) SEP

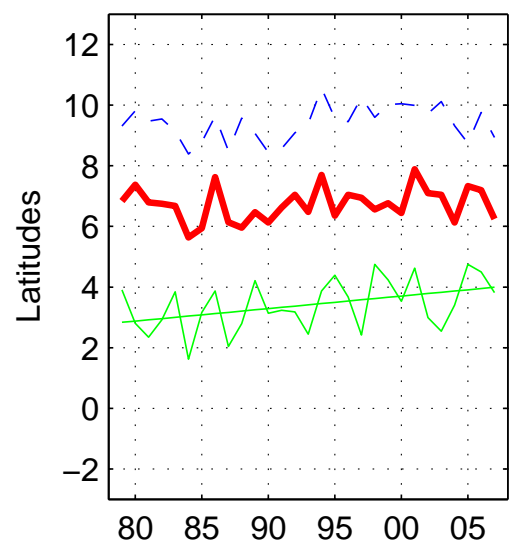

c) JUL

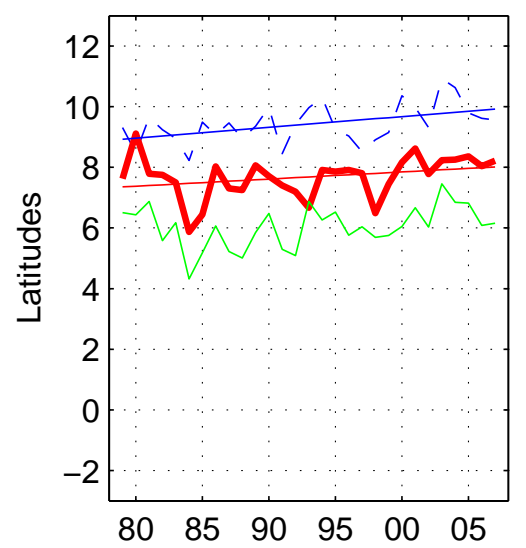

f) $\mathrm{OCT}$

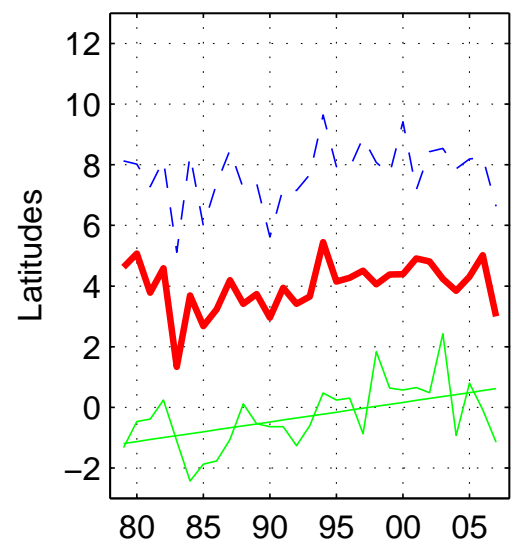

Figure 6: Interannual variability in the latitudinal location of OLR minima within the ITCZ over the longitudinal windows $15^{\circ} \mathrm{W}-0^{\circ}$ (blue), $0^{\circ}-15^{\circ} \mathrm{E}$ (red) and $15^{\circ} \mathrm{E}-30^{\circ} \mathrm{E}$ (green) and for different months of the period 1979-2007. Linear trends are superimposed when significant at $\mathrm{p}=0.1$ regarding the probability density function of Spearman's rank correlation coefficients, using 2000 resamplings through Monte Carlo simulations. 
a) Subsidence: MAY

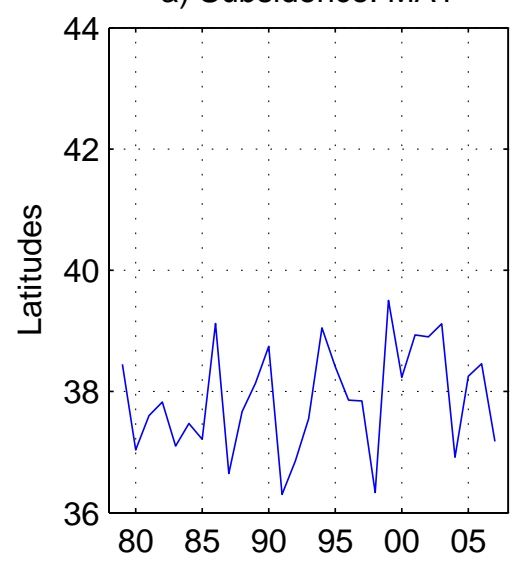

d) Subsidence: AUG

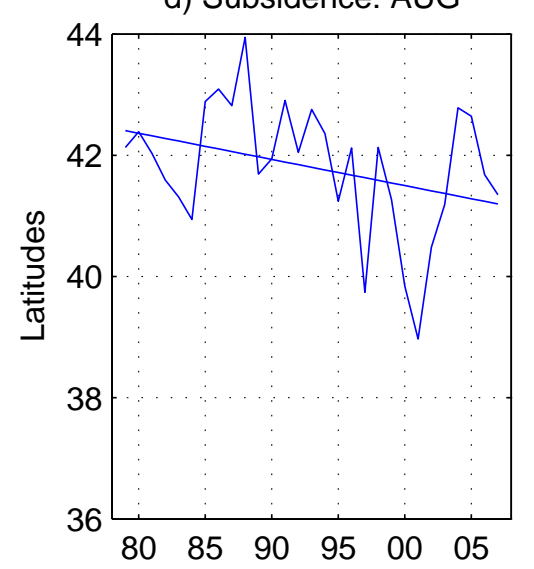

b) Subsidence: JUN

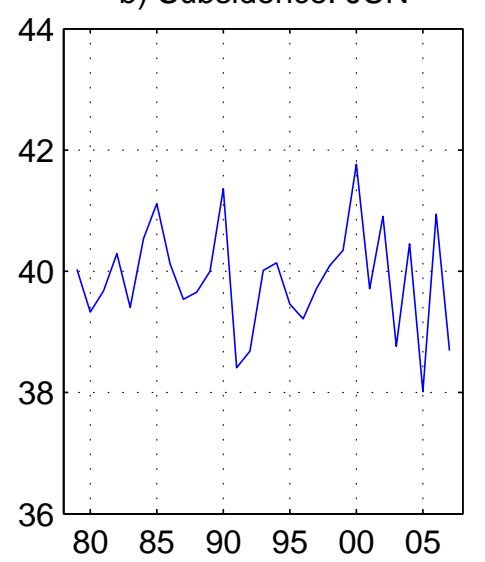

e) Subsidence: SEP

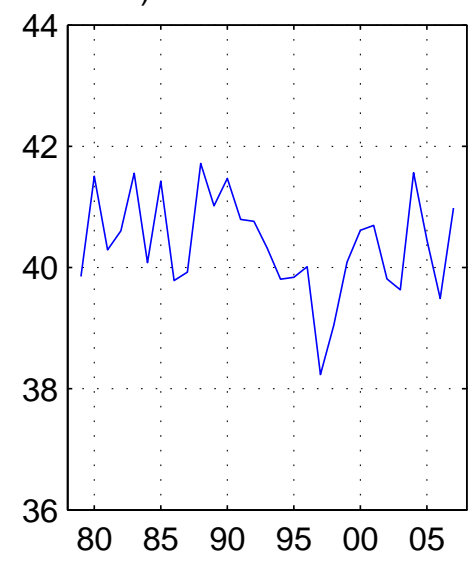

c) Subsidence: JUL

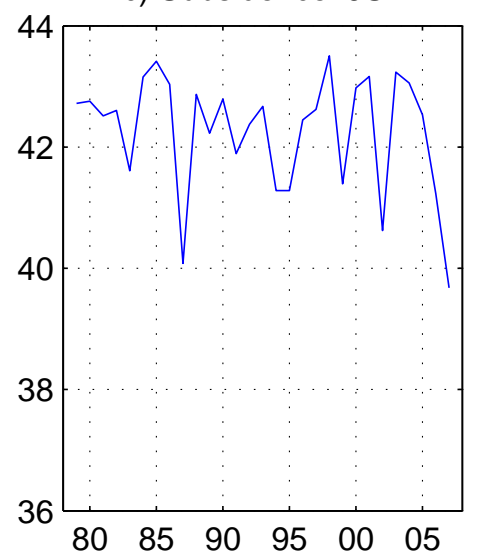

Figure 7: Interannual and linear trends in latitudinal locations of the poleward edges of the Hadley circulation, defined as the most poleward latitudes where the OLR equals $250 \mathrm{~W}$ m-2 as in $\mathrm{Hu}$ and $\mathrm{Fu}$ (2007) between $30^{\circ} \mathrm{W}$ and $30^{\circ} \mathrm{E}$ and for different months of the period 19792007. Linear trends are superimposed when significant at $\mathrm{p}=0.1$ regarding the probability density function of Spearman's rank correlation coefficients, using 2000 resamplings through Monte Carlo simulations. 
a) JFM 30W 30E mass flux 1979-2006

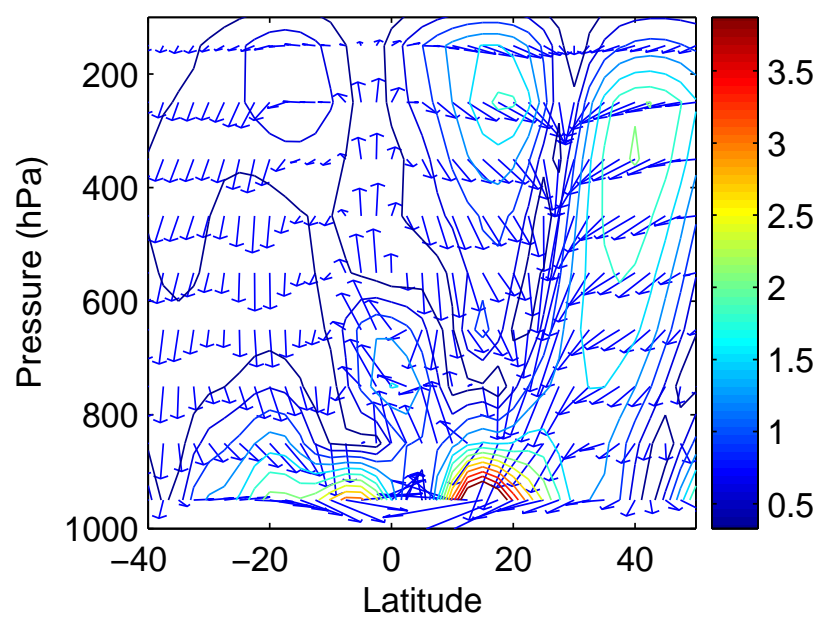

c) JAS 30W 30E mass flux 1979-2006

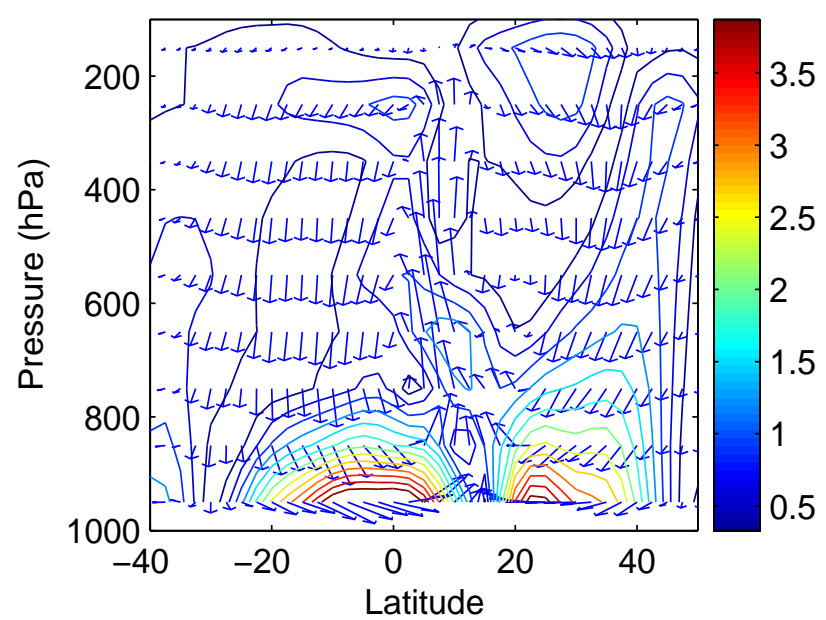

b) JFM 30W 30E mass flux (1993-2006)-(1979-1992)

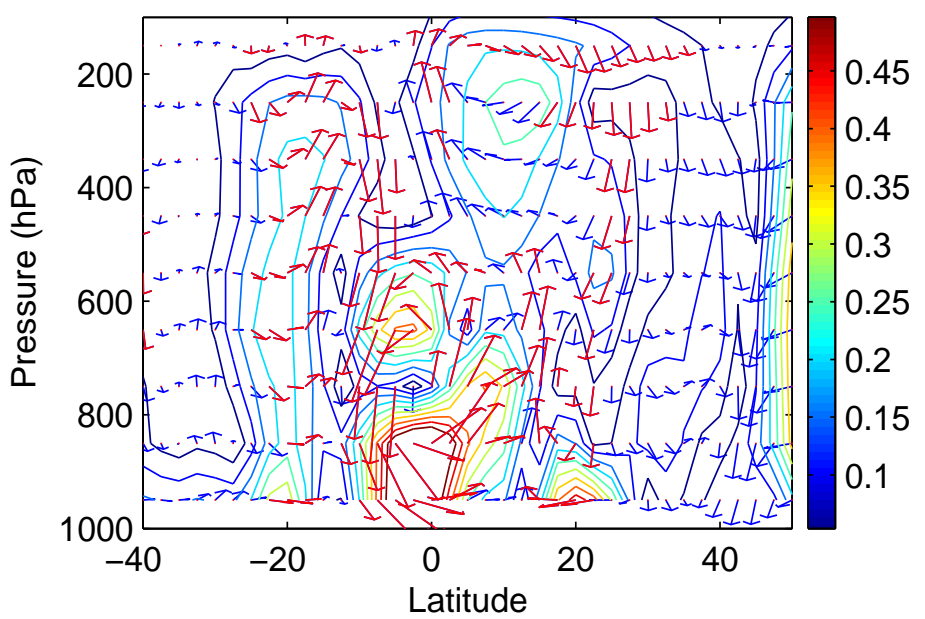

d) JAS 30W 30E mass flux (1993-2006)-(1979-1992)

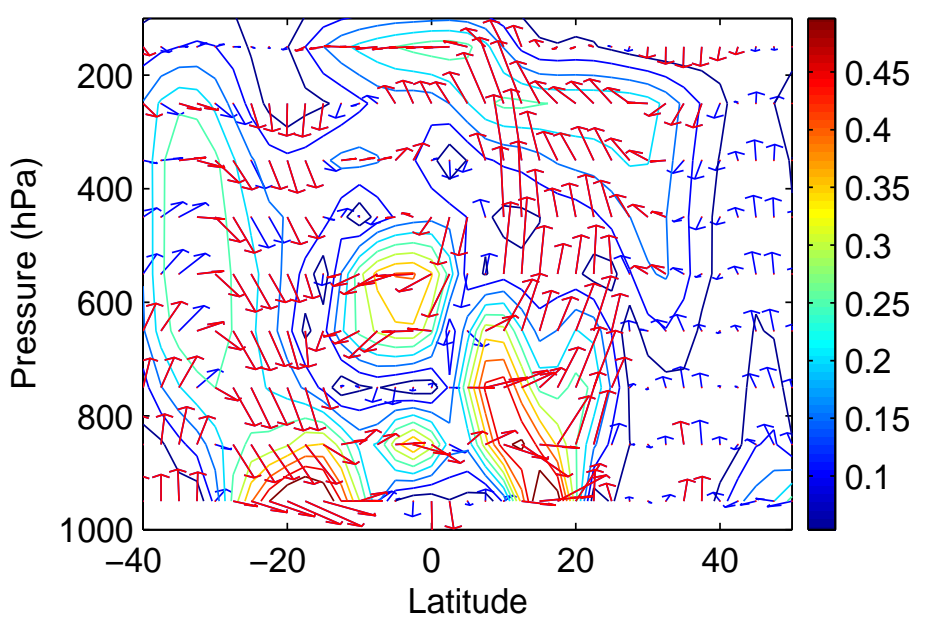

Fig. 8: (a,b) Latitude-pressure diagram of the meridional/vertical components of the mass flux averaged between $30^{\circ} \mathrm{E}$ and $30^{\circ} \mathrm{W}$ in January-March (a) and July-September (c) 1979-2006. (b,d) composite differences between subperiods 1993-2006 and 1979-1992.

Red arrows indicate Student's t-tests significant at the 5\% level. Contours indicate the magnitude of the vector, the units are in $\mathrm{kg} /\left(\mathrm{m}^{2} * \mathrm{~s}\right)$, contour intevals are 0.3 for the climatology and 0.05 for the anomalies. The vectors are drawn multiplying the vertical component by $10^{4}$. 
a) LT lat: 79-92(--), 93-06

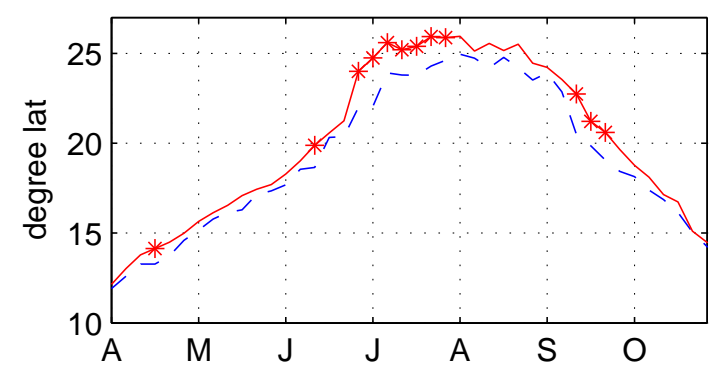

c) LT Ion: 79-92(--), 93-06

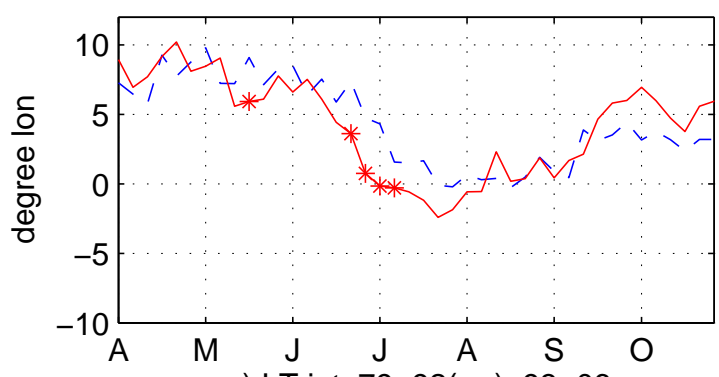

e) LT int: 79-92(--), 93-06

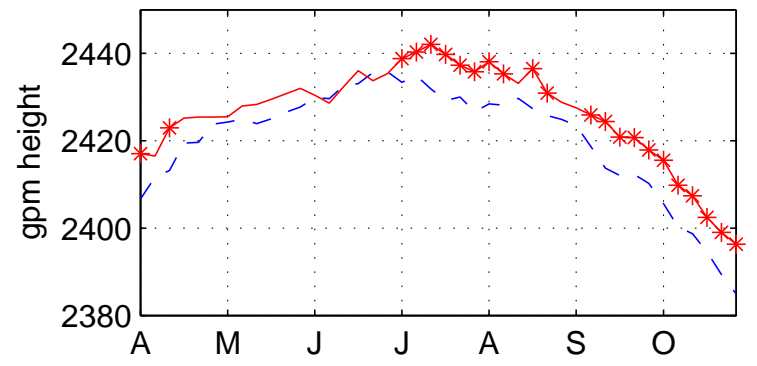

b) ST lat: 79-92(--), 93-06
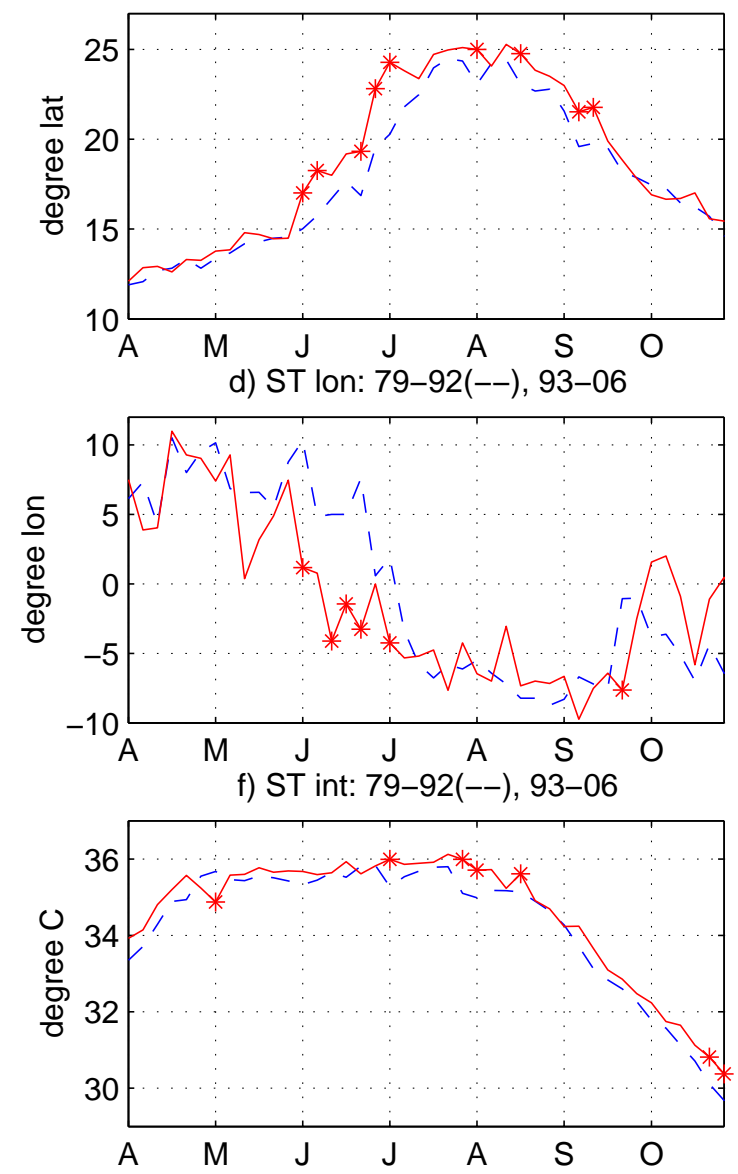

Figure 9: Mean April-October evolutions of the heat low indices (LT, left and ST, right) at a 5-day time step averaged over the periods 1979-1992 (dashed curves) and 1993-2006 (solid curves) in terms of $(a, b)$ latitudinal and longitudinal $(c, d)$ locations and of strength $(e, f)$. Location in degrees, LT intensity in gpm height, ST intensity in ${ }^{\circ} \mathrm{C}$. The significant composite differences between the 2 periods are marked by asters. The statistical significance has been tested through a Student paired-t-test at $\mathrm{p}=0.05$. 

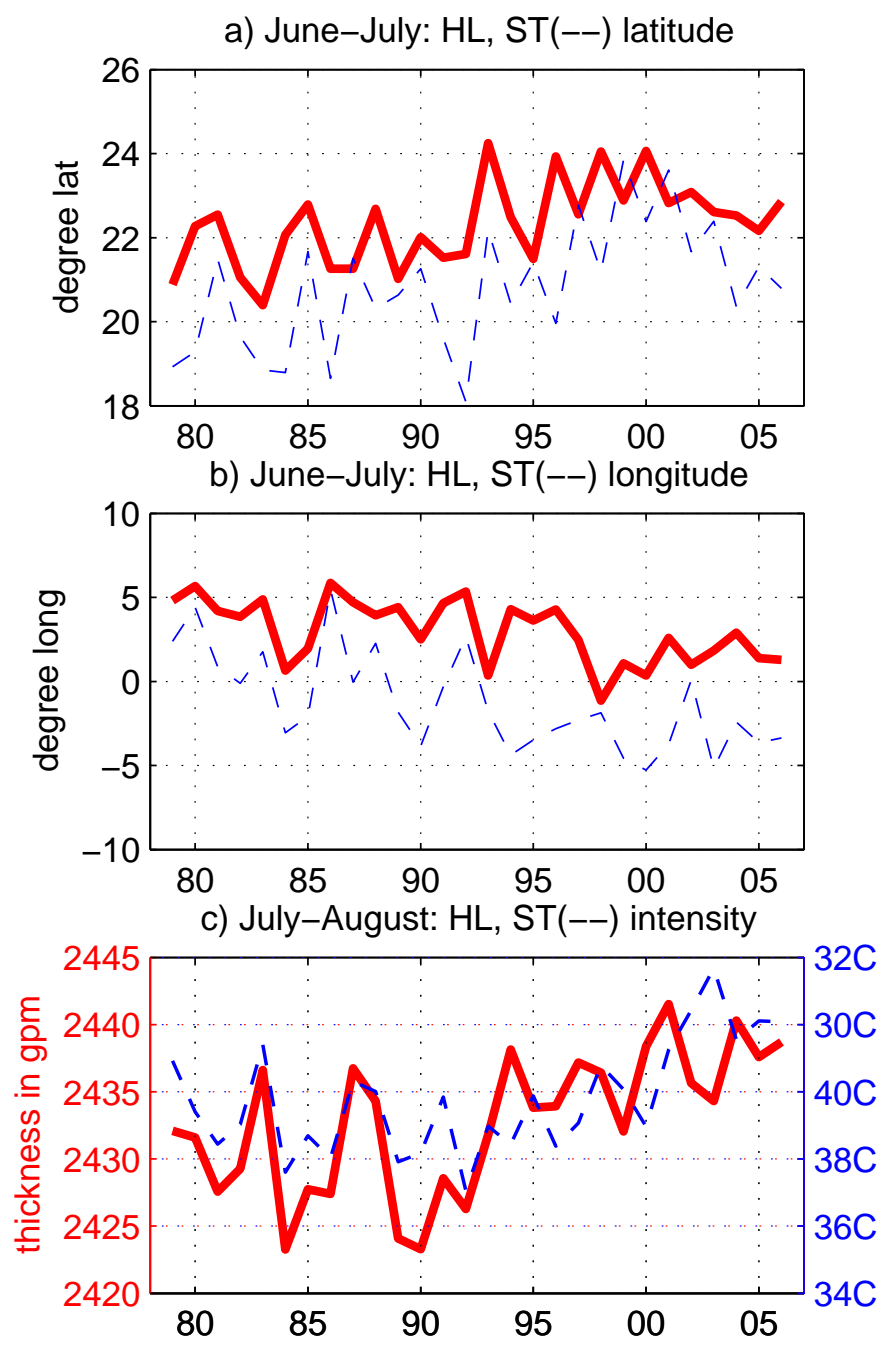

Figure 10: Interannual variability of the Heat low (solid/dashed curves for LT/ST over the period 1979-2006 : (a) latitude in June-July; (b) longitude in June-July; (c) strength in JulyAugust. Location in degrees, LT intensity in gpm height, ST intensity in ${ }^{\circ} \mathrm{C}$. 
a) MSLP in May-June

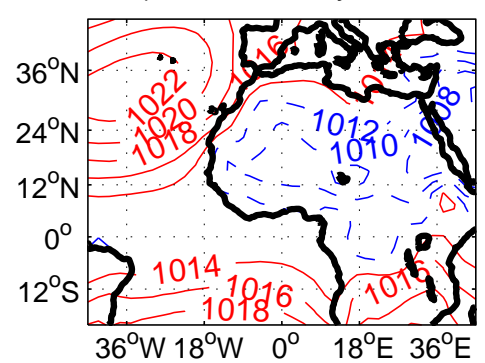

d) Diff in May-June

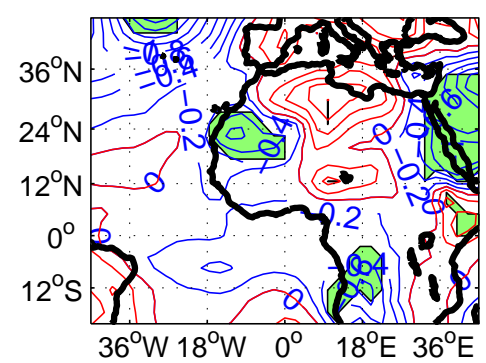

g) MSLP in May-June

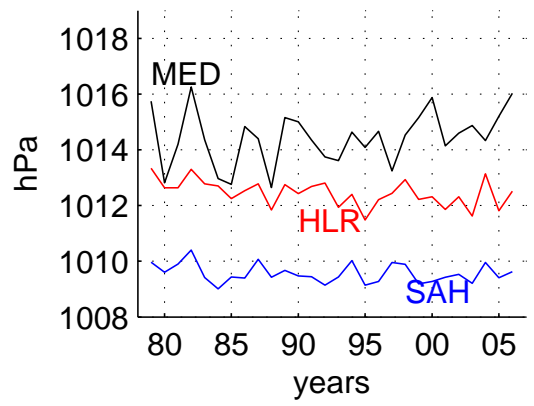

b) MSLP in July-Aug

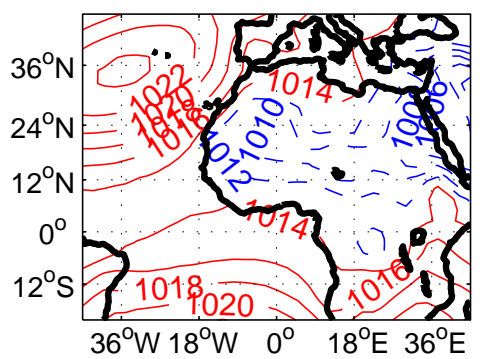

e) Diff in July-Aug

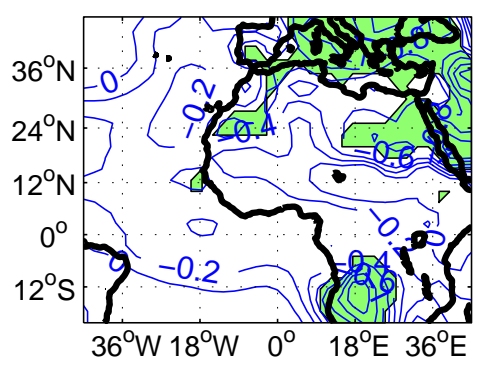

h) MSLP in July-Aug

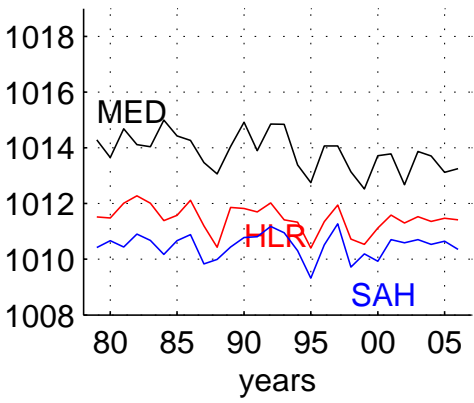

c) MSLP in Sept-Oct

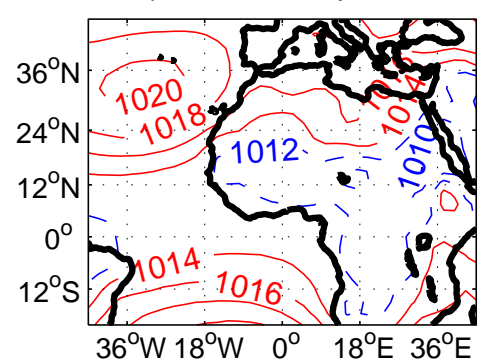

f) Diff in Sept-Oct
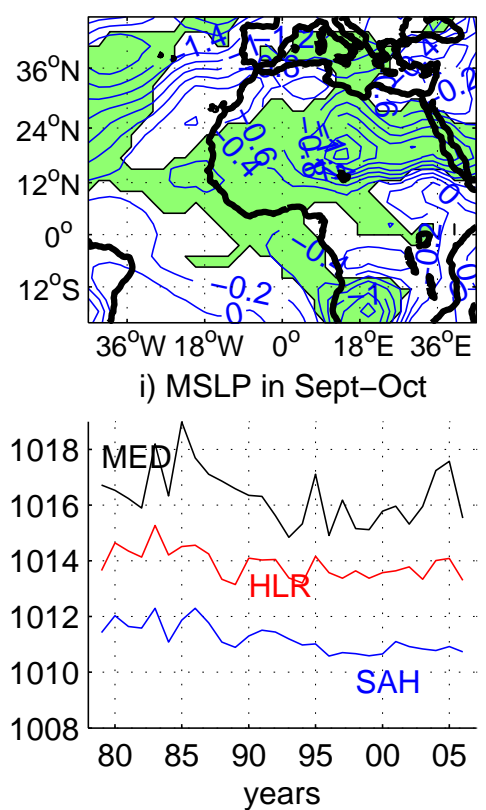

Figure 11: Mean Sea Level Pressure (MSLP) bi-monthly means (a-c) and [1994-2006] minus [1979-1993] composites (d-f) along with time evolutions of regional indices averaged over selected areas: Mediterranean (MED: $0^{\circ}-30^{\circ} \mathrm{E} ; 30^{\circ} \mathrm{N}-45^{\circ} \mathrm{N}$ ), the Heat Low Region (HLR: $\left.15^{\circ} \mathrm{W}-0^{\circ} ; 20^{\circ} \mathrm{N}-30^{\circ} \mathrm{N}\right)$ and the Sahelian band (SAH: $\left.15^{\circ} \mathrm{W}-30^{\circ} \mathrm{E} ; 10^{\circ} \mathrm{N}-20^{\circ} \mathrm{N}\right)$. The significant composite differences between the 2 periods are marked by shadings. The statistical significance has been tested through a Student paired-t-test at $p=0.05$. 
a) : Temp in JAS

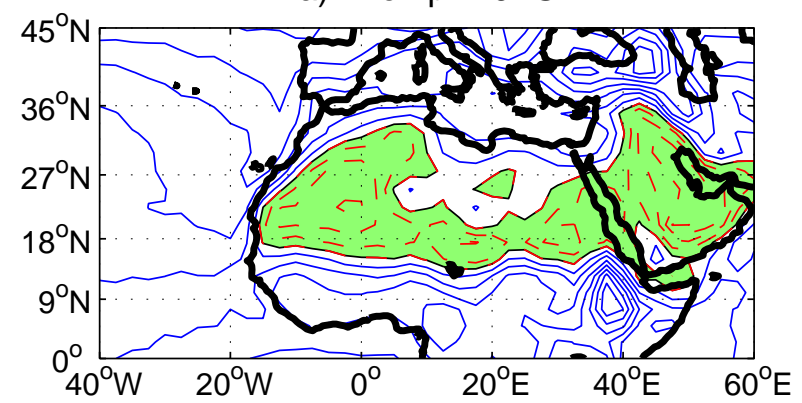

c) : OMEGA400 in JAS

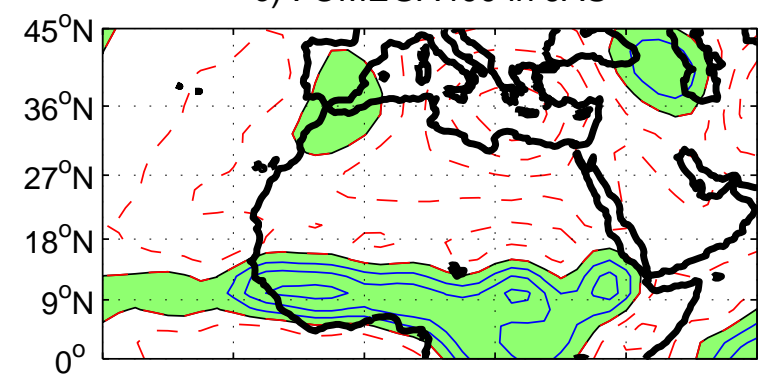

e) : W925 in JAS

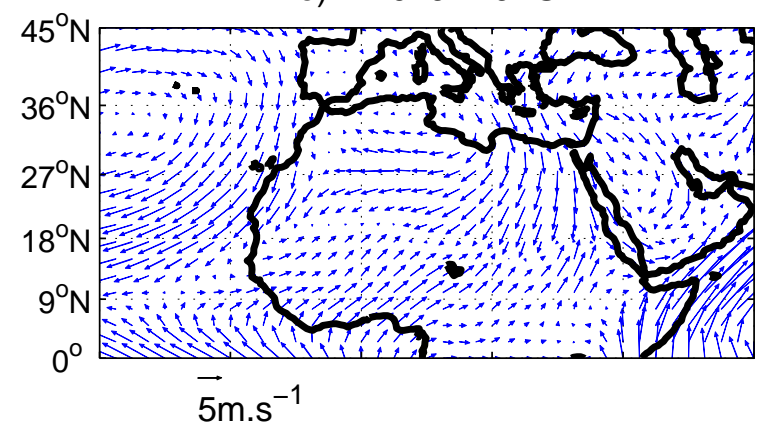

b) : Temp(diff)

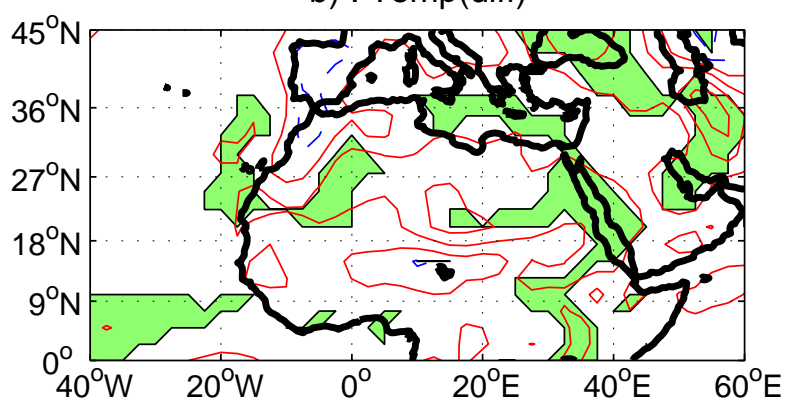

d) : OMEGA400(diff)

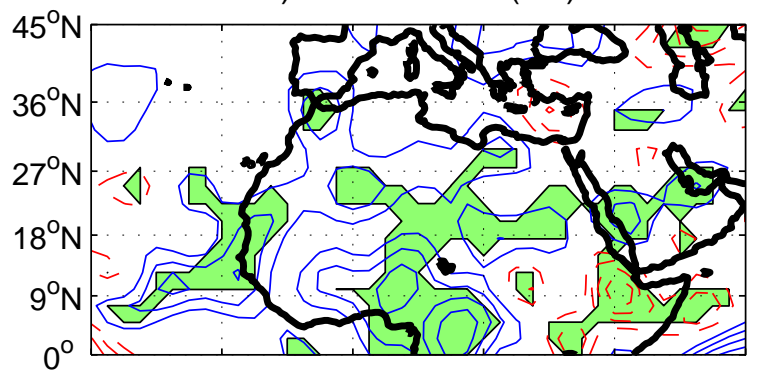

f) : W925(diff)

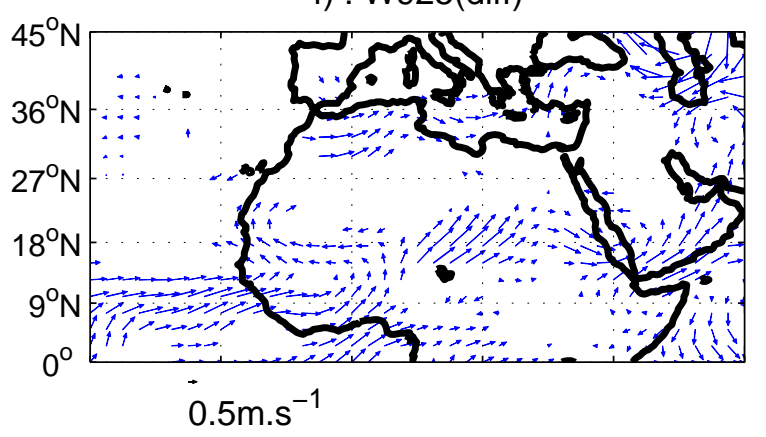

Figure 12: Surface temperature $\left({ }^{\circ} \mathrm{C}\right)$, omega at $400 \mathrm{hPa}(\mathrm{Pa} / \mathrm{s})$ and wind at $925 \mathrm{hPa}$ (vectors) fields in July-September: mean fields at left and significant composite differences between the two half periods 1994-2007 and 1979-1992 at right. Red (blue) curves for (a) temperatures higher (lower) than $30^{\circ} \mathrm{C}$, isolines varying by $2^{\circ} \mathrm{C}$; (b) positive (negative) temperature differences by $0.5^{\circ} \mathrm{C}$; (c) downward (upward) motion; (d) positive (negative) omega differences; (e) wind at $950 \mathrm{hPa}$; (f) significant wind differences at $950 \mathrm{hPa}$. Shaded areas when temperature $>30^{\circ} \mathrm{C}$ (a), subsidence (b) and the significant composite differences (b,d). The statistical significance has been tested through a Student paired-t-test at $\mathrm{p}=0.05$. 
a) : W200 in JAS
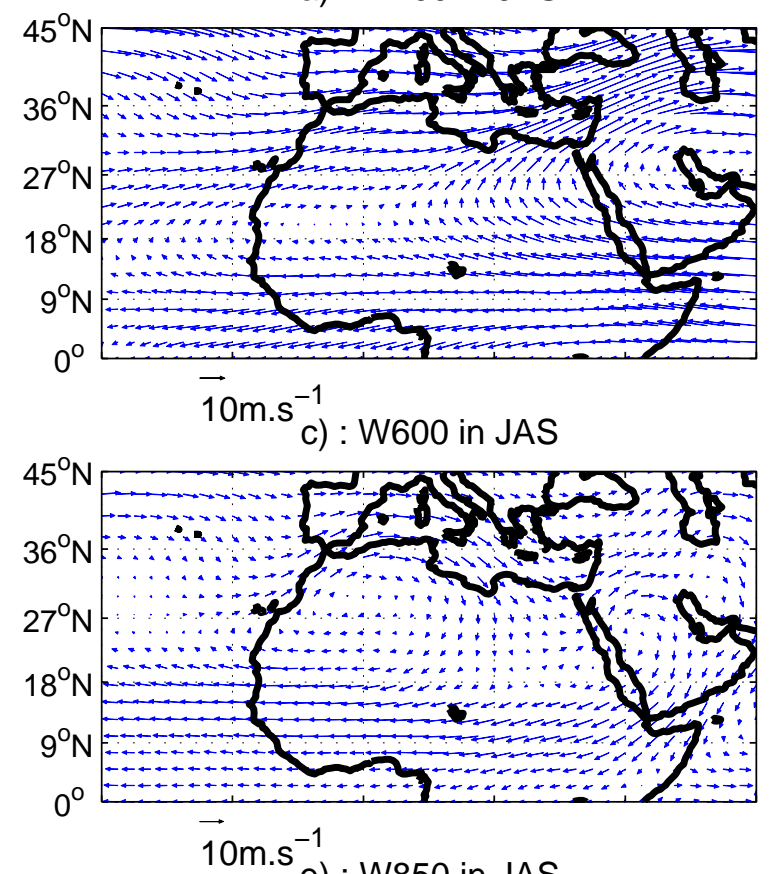

e) : W850 in JAS

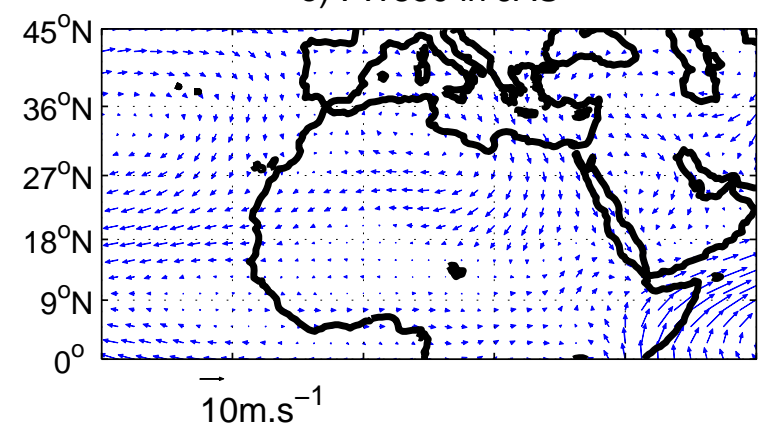

b) : W200(diff)
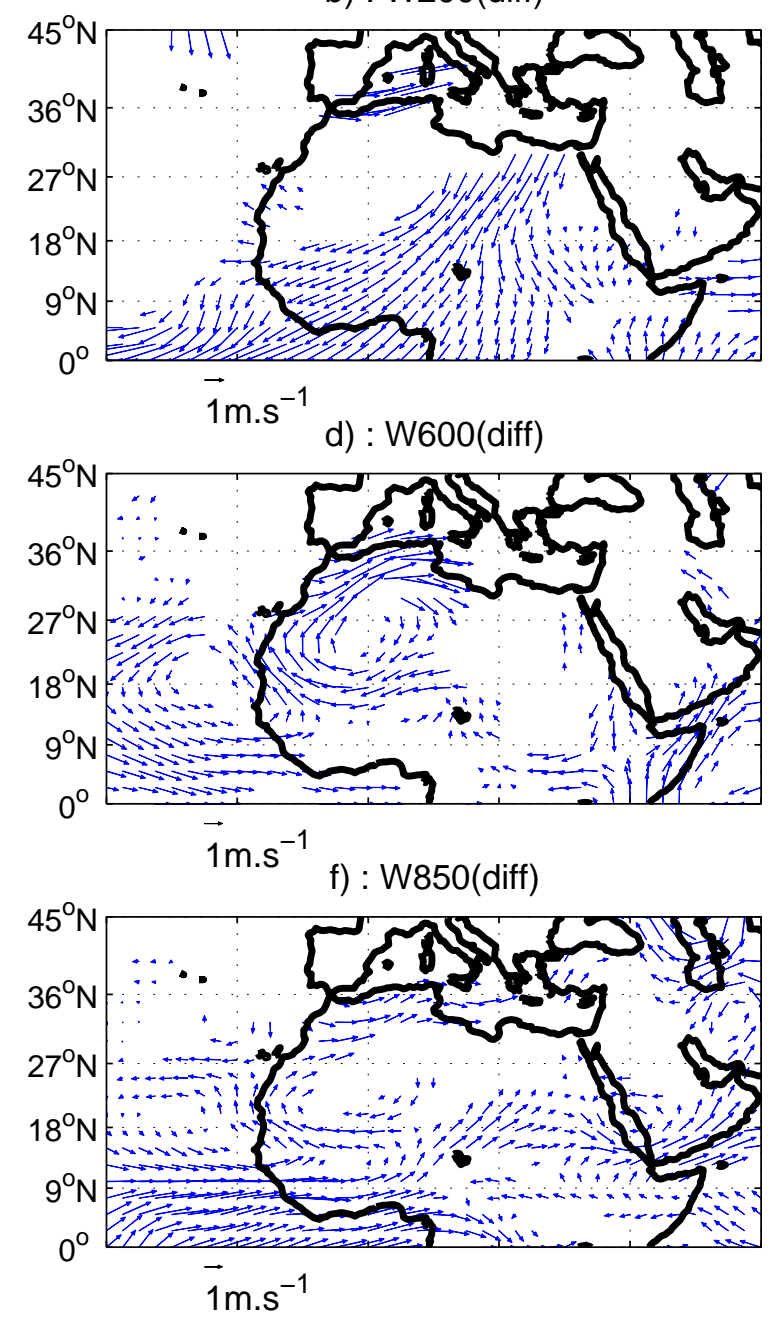

Figure 13: as bottom panels in figure 12 but for the isobaric levels 200, 600 and $850 \mathrm{hPa}$. 

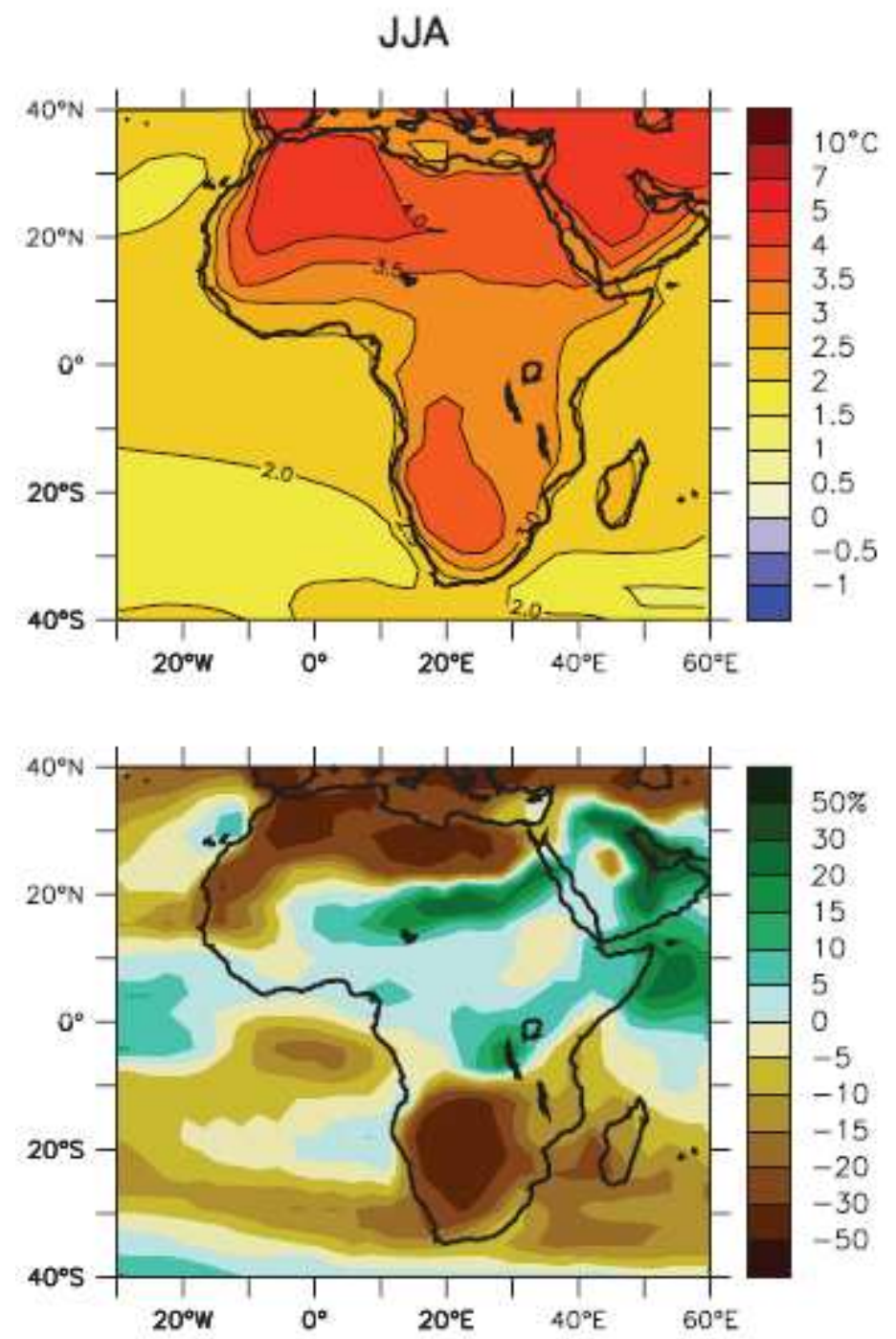

Figure 14: Temperature and precipitation changes over Africa from the multi-model data set (A1B simulations). Top: JJA temperature change between 1980 to 1999 and 2080 to 2099, averaged over 21 models. Bottom: same as top, but for fractional change in precipitation (from Christensen et al., 2007. ) 
a) u moisture flux (CNRM): CTL
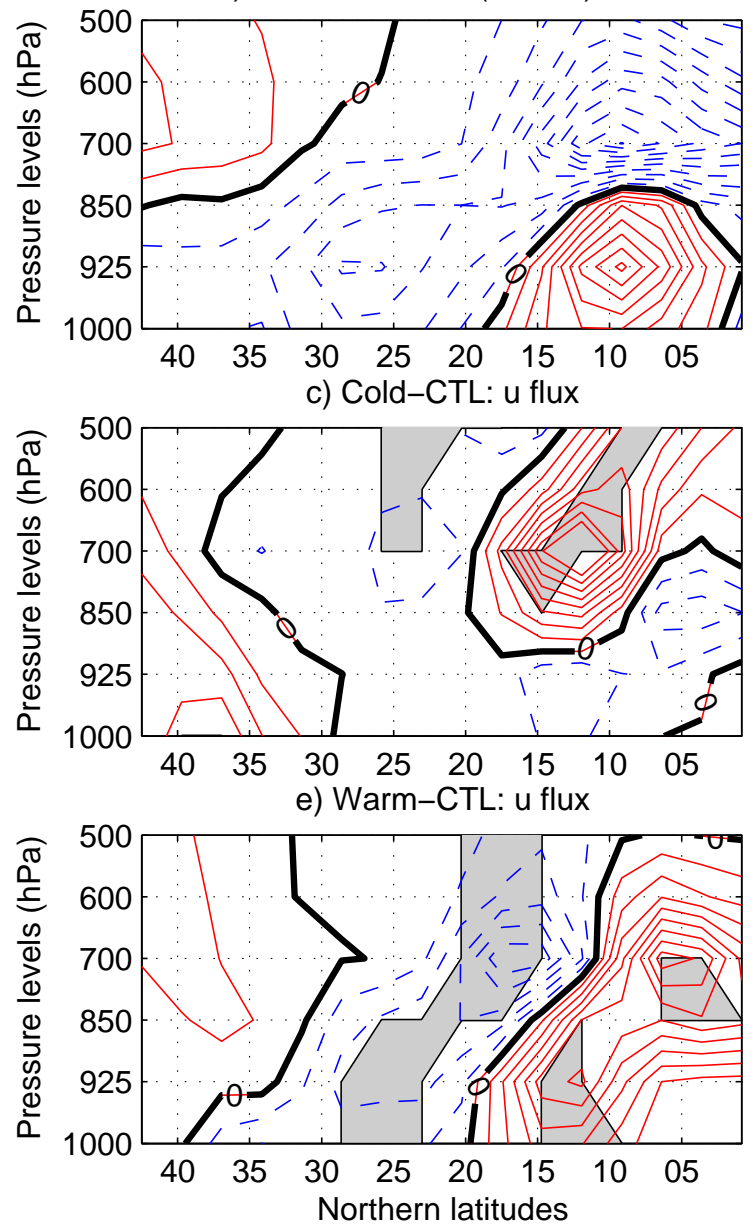

b) v moisture flux (CNRM): CTL
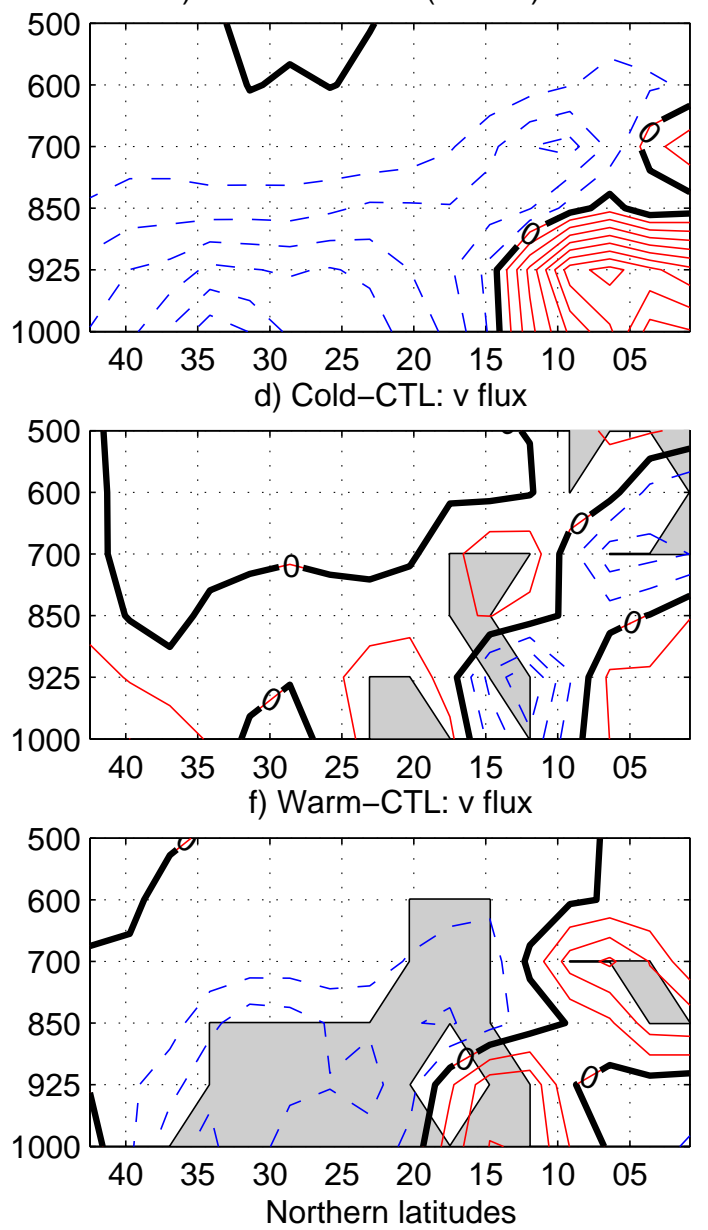

Figure 15: Vertical-meridional cross sections between $20^{\circ} \mathrm{W}$ and $30^{\circ} \mathrm{E}$ of mean and composite moisture fluxes from sensitivity experiments on the ARPEGE-Climat Version 3 IPCC-AR4 in truncature 42 with 45 levels run at Centre National de Recherches Météorologiques (see the text for more details).

(a,b) : $\mathrm{u}$ and $\mathrm{v}$ mean components from the 20 April-September control runs; isolines each $5 \mathrm{~m} \mathrm{~s}^{-1} \mathrm{~g} \mathrm{Kg}^{-1}$

c,d (e,f) : composite differences between the 20 cold (20 warm) simulations and 20 control simulations; isolines each $0.5 \mathrm{~m} \mathrm{~s}^{-1} \mathrm{~g} \mathrm{Kg}^{-1}$

The solid (dashed) contours refer to the positive (negative) differences. In panels c-f, shadings are superimposed when composite differences are significant at $\mathrm{p}=0.10$ regarding a Student $\mathrm{t}$ test. 